
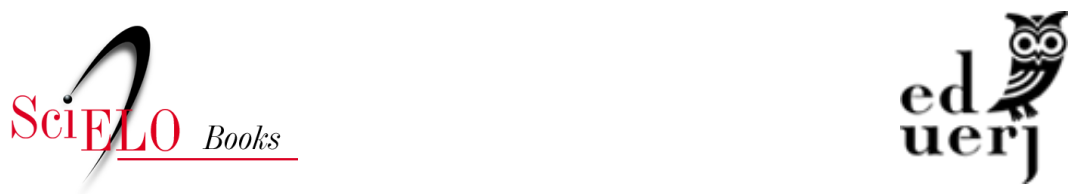

\title{
4. A expansão do capitalismo brasileiro na América do Sul
}

\author{
Tiago Nery
}

\section{SciELO Books / SciELO Livros / SciELO Libros}

NERY, T. A expansão do capitalismo brasileiro na América do Sul. In: A política externa brasileira e a UNASUL: geopolítica e expansão do capitalismo brasileiro na América do Sul [online]. Rio de Janeiro: EDUERJ, 2021, pp. 267-341.

Sociedade e política collection. ISBN: 978-65-87949-19-2.

https://doi.org/10.7476/9786587949192.0006.

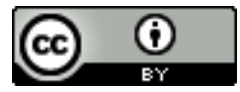

All the contents of this work, except where otherwise noted, is licensed under a Creative Commons Attribution 4.0 International license.

Todo o conteúdo deste trabalho, exceto quando houver ressalva, é publicado sob a licença Creative Commons Atribição 4.0.

Todo el contenido de esta obra, excepto donde se indique lo contrario, está bajo licencia de la licencia Creative Commons Reconocimento 4.0. 


\section{A expansão dO CAPITALismo brasileiro NA AmÉriCA do Sul}

Este capítulo trata do capitalismo brasileiro, de sua consolidação e de sua recente expansão na América do Sul. A primeira seção analisa as diferentes trajetórias do desenvolvimento capitalista na América Latina e no Leste Asiático após a Segunda Guerra Mundial. Para compreender as distintas trajetórias, analisam-se os processos de constituição dos Estados, as relações entre a burocracia pública e o setor privado e o grau de participação do investimento externo na economia. Ao contrário dos países latino-americanos, os países asiáticos realizaram profundas reformas estruturais, fortaleceram as capacidades burocráticas e criaram empresas líderes em setores dinâmicos. $\mathrm{O}$ resultado foi a divergência nos caminhos percorridos pelos países de industrialização tardia, com a consolidação de um modelo de desenvolvimento nacionalista ou autônomo no Leste Asiático e de um modelo de desenvolvimento dependente na América Latina.

$\mathrm{Na}$ segunda seção, procura-se analisar o processo de consolidação do capitalismo de Estado no Brasil e a expansão da fronteira econômica brasileira nos últimos anos. Historicamente, o BNDES exerceu um papel fundamental na industrialização do país e no fortalecimento do setor privado nacional, e, nos últimos anos, o Banco tem apoiado a internacionalização das empresas brasileiras. A presença econômica brasileira na América do Sul ganhou um novo impulso a partir do governo Lula e tornou-se uma das dimensões de sua política exterior. $\mathrm{O}$ impacto negativo das grandes obras realizadas pelas empreiteiras brasileiras atinge a agenda político-diplomá- 
tica e gera uma percepção nos vizinhos de que o Brasil seria um país subimperialista. No entanto, a noção de subimperialismo mostra-se em contradição com esquemas cooperativos, como a Unasul.

Na terceira e última seção, são analisadas a histórica fragmentação do território sul-americano, a proposta de integração física apresentada pelos governos neoliberais e as tentativas de modificação dessa proposta pelas forças progressistas que assumiram o poder no início do século XXI. Em 2000, o governo Fernando Henrique apresentou a IIRSA, iniciativa de integração da infraestrutura baseada em uma visão geoeconômica que priorizava a formação de corredores de exportação/importação para escoar produtos de baixo valor agregado. Com a mudança do signo ideológico dos governos, iniciou-se um processo de incorporação da IIRSA à Unasul, concretizada com a criação do Cosiplan. No entanto, a infraestrutura sul-americana ainda carece de financiamento, de planejamento regional e de mais participação da sociedade. O capítulo se encerra com uma breve síntese dos principais temas tratados ao longo das seções.

\subsection{A ascensão do "resto" e as diferentes trajetórias da América Latina e da Ásia}

A presente seção trata das diferenças entre as trajetórias de desenvolvimento da América Latina e do Leste Asiático após a Segunda Guerra Mundial. Para compreender os diferentes resultados alcançados, é preciso analisar a constituição dos Estados, as capacidades burocráticas e os tipos de vínculo forjados entre as economias nacionais e a economia global. Nas duas regióes, o Estado somente cumpriu as funções desempenhadas devido a relações específicas com o capitalismo internacional constitutivas de sua própria natureza. Dessa forma, foram os processos históricos de formação - o embate das forças políticas internas e destas com o sistema mundial - que determinaram a natureza dos Estados, os padrões de intervenção e os resultados econômicos. 
Em seu último livro, John Kenneth Galbraith (2004) afirma que muitos acadêmicos, empresários e jornalistas costumam adotar a expressão "sistema de mercado" no lugar de "capitalismo", cuja palavra evoca de modo muito estridente o poder da propriedade e a submissão dos trabalhadores e demais pessoas. Na grande mídia, analistas do sistema financeiro são constantemente convidados para falar do "mercado", tratado como um ente autônomo e dotado de racionalidade. No entanto, ainda segundo o autor, referir-se ao sistema de mercado, expressão sem história, como uma alternativa benigna ao capitalismo, constitui uma fraude não de todo inocente, sobretudo em um período de aumento das desigualdades e de crescente precarização das relações de trabalho em todo o mundo.

A ideia de uma economia pura, desprovida de toda e qualquer instituição jurídica ou política, não corresponde à realidade. $\mathrm{O}$ mercado, por exemplo, é uma instituição que pressupõe um acordo referente à qualidade, à organização das trocas, às condições de acesso e ao modo de pagamento das transações. Trata-se de uma construção social, e não o resultado de forças naturais ou espontâneas. Não é possível, portanto, construir uma economia pura, pois as instituições econômicas estão inseridas em um espaço social e político. Diante da complexidade das relações sociais, é discutível postular a existência de uma única forma de capitalismo em direção à qual todas as outras estariam condenadas a convergir. Como cada formação social resulta de uma sequência original de lutas, de compromissos políticos e estruturas econômicas, é possível se referir a diferentes formas de capitalismo (Boyer, 2009).

Ao caracterizar as mudanças institucionais no sistema capitalista, a literatura sobre variedades de capitalismo costuma adotar uma visão primeiro-mundista, relegando os países da periferia ao segundo plano. A posição estrutural que esses países ocupam no sistema internacional deve ser tratada como um traço constitutivo dos seus regimes produtivos, além de determinante para o desempenho dessas economias. Apesar de algumas abordagens adotarem um 
olhar latino-americano sobre as questões de desenvolvimento, até recentemente as análises não incluíam o Estado como principal ator estratégico na periferia (Boschi, 2011). ${ }^{1}$ Contudo, independentemente dos estudos sobre variedades de capitalismo, muitos autores sempre destacaram o papel das instituições estatais na constituição dos regimes produtivos dos países em desenvolvimento.

Nos anos 1980, tornou-se comum ouvir o argumento de que países como Coreia do Sul e Taiwan se desenvolveram ao adotarem políticas liberais e de promoção a exportações, ao contrário do modelo substitutivo adotado pela América Latina. Em 1993, o Banco Mundial publicou um relatório - The East Asia Miracle: economic growth and public policy - que se mostrou incapaz de explicar como as nações asiáticas haviam alcançado taxas de crescimento elevadas, reforçando o mito do "milagre asiático". Apesar da importância da intervenção estatal no desenvolvimento desses países, em muitas passagens os autores sentiam-se na obrigação de questionar a correlação positiva entre as políticas implementadas e os resultados econômicos obtidos, afirmando que o máximo que se podia concluir era que tais políticas não atrapalharam. Ao apoiar-se em uma distinção absoluta entre mercado e intervenção estatal, o argumento do Banco Mundial tornou-se contraditório, demonstrando a dificuldade de alguns analistas aceitarem os limites de suas teorias para compreender as especificidades dos países em desenvolvimento. Todavia, os chamados "tigres asiáticos" acabaram

1 Preliminarmente, cumpre esclarecer que este trabalho não adota as tipologias utilizadas pela literatura de variedades de capitalismo. Segundo Ben Ross Schneider (2013), o sistema capitalista possui um número limitado de mecanismos alternativos de alocação de recursos, que envolvem ganhos relativos a investimento, produção e trocas. Apoiando-se em tipo ideais, a maioria dos autores identifica quatro mecanismos de alocação - mercados, negociação, confiança e hierarquia - que correspondem a distintas formas de organizar o capitalismo: liberal market economies (LME), coordinated market economies (CME), network market economies (NME) e hierarchical market economies (HME). Schneider considera as economias latino-americanas como próximas ao modelo HME, enquanto as asiáticas estariam entre os tipos CME e NME. 
prestando um grande serviço à teoria do desenvolvimento ao dotá-la de fundamentação empírica para desmascarar os mitos convencionais sobre a superioridade do Estado mínimo. Na realidade, o livre comércio como "estratégia de alcançamento" (catch up) se restringiu a Honk Kong e à Suíça, já que apenas esses países tinham os ativos necessários para construir suas indústrias sem serem devastados por importaçóes ou impedidos de exportar. $\mathrm{Na}$ ausência de ativos comparáveis, outros retardatários precisaram adotar instituições diferentes do livre mercado para se desenvolverem (Amsden, 2009; Evans, 2014; Goldenstein, 1994; Kohli, 2009; Rodrik, 2011).

Após a Segunda Guerra Mundial, o mundo atravessou um momento eufórico marcado pelos processos de descolonização e pela hegemonia da teoria do desenvolvimento e suas ideias sobre planejamento econômico. Foram os "Trinta anos dourados do capitalismo", caracterizados pelo regime de acumulação fordista - apoiado na produção e no consumo de massas - e pelo modo de regulação keynesiano - responsável por políticas de estabilização da conjuntura. Apesar de o fordismo nunca ter sido hegemônico no Sul, onde o setor manufatureiro sempre conviveu com elevada informalidade, o período do pós-guerra mudou a maneira como os governos concebiam o envolvimento do Estado na economia. Nesse sentido, ocorreu uma virada ideológica no mundo não socialista que levou os Estados a aumentarem sua participação no domínio econômico. Assim, a ideia de um Estado forte se impôs como expressão da modernidade, situação que só seria modificada trinta anos depois, quando o consenso keynesiano deu lugar ao consenso neoliberal (Boyer, 2009; Bresser-Pereira, 2014; Diniz, 2011; Musacchio e Lazzarini, 2015).

A ascensão dos países que Alice Amsden (2009) chamou de "resto" foi uma das mudanças mais impressionantes da segunda metade do século XX. ${ }^{2}$ Para compensar seu atraso histórico, os

2 Segundo Amsden (2009), o "resto" compreende os países que tinham experiência manufatureira acumulada no período pré-guerra, tais como: China, Índia, Indonésia, Coreia do Sul, Malásia, Taiwan e Tailândia, na Ásia; Argentina, Brasil, Chile e 
países periféricos optaram por uma solução institucional intervencionista. $\mathrm{O}$ "resto" ascendeu a partir da concepção de um modelo econômico original e heterodoxo que se apoiava em mecanismos de controle, que eram instituições responsáveis por disciplinar o comportamento da economia, a exemplo das políticas industriais ativas, com seus respectivos padrões de desempenho, e dos bancos de desenvolvimento. Com exceção da Argentina, mecanismos de controle foram construídos em todo o "resto", entre as décadas de 1950 e 1960. Não obstante, uma divisão fundamental surgiu em seu interior, entre os "integracionistas" e os "independentes", ou entre um modelo de desenvolvimento nacionalista, no Leste Asiático, e um modelo de desenvolvimento dependente, na América Latina. Uma das principais diferenças entre ambos está no grau de controle estrangeiro da estrutura produtiva. Entre os fatores que explicam as diferentes trajetórias, destacam-se a questão geopolítica, a formação dos Estados e a experiência manufatureira (Amsden, 2009; Kohli, 2009).

Para Atul Kohli (2009), os diferentes caminhos percorridos por Ásia e América Latina têm profundas raízes políticas. O grau de autonomia política em relação aos constrangimentos globais reflete os distintos processos de formação estatal nas duas regiões, sobretudo após a Segunda Guerra Mundial. De maneira geral, pode-se afirmar que as lutas pela descolonização na Ásia criaram descontinuidades significativas, levando a modificações nas relações de classe, alterando as relações externas e possibilitando aos Estados maior autonomia na determinação das políticas de desenvolvimento. Já na América Latina, houve mais continuidade do que mudança na base social, no poder estatal, nos padrões de dependência em relação à

México, na América Latina; e Turquia, no Oriente Médio. Já o "resquício" inclui os países que foram menos expostos à moderna vida fabril no pré-guerra, o que os impossibilitou de se aproximar da diversificação industrial do "resto", a exemplo de Filipinas, Paquistão, Egito, Colômbia, Equador e Venezuela. 
potência hegemônica e nas possibilidades de implementar projetos de desenvolvimento autônomos.

Uma análise da experiência asiática permite concluir que a interação de uma especial localização geográfica com impactos geopolíticos possibilitou uma determinada inserção internacional e certa configuração interna de interesses hegemônicos. $O$ processo de descolonização e as lutas revolucionárias em alguns países, como na China e no Vietnã, contribuíram para que os novos Estados enfatizassem a autonomia nacional em relação às antigas potências coloniais e aos Estados Unidos. Nos casos de Coreia do Sul e Taiwan, as relaçóes de dependência com os norte-americanos se limitavam a questóes de segurança, pois ambos tiveram ampla liberdade para adotar estratégias de desenvolvimento, inclusive com apoio estadunidense (Goldenstein, 1994; Kohli, 2009).

As tensões geopolíticas foram fundamentais para viabilizar reformas agrárias profundas, que resultaram na eliminação das elites rurais no Leste Asiático após a Segunda Guerra Mundial. No caso da Coreia do Sul, condições internas permitiram que os Estados Unidos apoiassem a reforma, pois parte das terras era controlada pelos japoneses e parte era de propriedade de agricultores locais que os haviam apoiado. A reforma agrária retardou o aumento do consumo interno, permitindo altas taxas de poupança interna, e, nos países onde foi realizada, contribuiu para reduzir as desigualdades de riqueza e poder, além de fortalecer as capacidades estatais. De fato, a reforma agrária do pós-guerra na Coreia do Sul, no Japão e em Taiwan resultou em sociedades mais igualitárias. Em contraste, na América Latina, a relação dos Estados Unidos com as elites rurais atrapalhou a realização da reforma, contribuindo para a concentração da riqueza. Historicamente, a propriedade da terra constituiu-se em um dos traços marcantes da sociedade latino-americana, base de um sistema de dominação a serviço de uma pequena minoria (Amsden, 2009; Evans, 2014; Furtado, 2007; Goldenstein, 1994; Kohli, 2009). 
No caso da reforma agrária, o argumento mais forte para defendê-la não se baseava em aspectos relacionados à produtividade, mas em seu impacto distributivo. Como destacou o historiador Eric Hobsbawm (1995, p. 348), "[...] enquanto a desigualdade de renda atingia seu ponto mais alto na América Latina, seguida pela África, era em geral baixa em vários países asiáticos, onde uma reforma agrária bastante radical fora imposta sob os auspícios das forças de ocupação americana (ou por seu intermédio): Japão, Coreia do Sul e Taiwan". Sem dúvida, a questão geopolítica influenciou fortemente o alcance das reformas estruturais nas duas regiões. Enquanto a Revolução Chinesa e a existência da Coreia do Norte representaram um bônus geopolítico para países como Coreia do Sul e Taiwan, a proximidade da América Latina em relação aos Estados Unidos significou um ônus geopolítico, levando a potência norte-americana a intervir sempre que algum governo da região ameaçava realizar políticas de reforma social.

A eliminação da elite rural, a existência de uma burguesia fraca e, em alguns casos, a ajuda norte-americana contribuíram para o fortalecimento do Estado no Leste Asiático. As capacidades burocráticas dos países da região são as que mais se aproximam do tipo ideal de burocracia weberiana, com recrutamento meritocrático e carreiras estruturadas. Há uma estreita conexão entre as elites burocráticas e o setor privado, relação que é incentivada por governos comprometidos com projetos de desenvolvimento nacional. Ao invés de propiciar formas predatórias de articulação empresário-Estado, os vínculos entre os setores público e privado levaram a esforços cooperativos que aprofundaram a industrialização e contribuíram para a implementação de objetivos abrangentes de longo prazo. Nesse sentido, a manutenção de laços próximos com a elite empresarial, evitando ser capturado por ela e dispondo de instrumentos para discipliná-la, constitui uma característica central do Estado desenvolvimentista asiático, que o diferencia das experiências latino-americanas. Além disso, as coalizões de classe do Leste 
Asiático mantiveram o seu compromisso com estratégias nacionais de desenvolvimento, ao contrário das coalizões da América Latina, sobretudo no Brasil, onde as elites sempre foram marcadas pela ambiguidade, em alguns momentos identificando-se com o nacionalismo democrático, em outros adotando posturas liberais e dependentes (Bresser-Pereira, 2014; Diniz, 2011; Evans, 2014).

De alguma maneira, as diferentes capacidades estatais tiveram impacto sobre os níveis de igualdade em função dos investimentos sociais realizados. Ao contrário do que ocorreu na América Latina, os países do Leste Asiático estruturaram sistemas tributários progressivos, tributando os estratos sociais mais ricos e possibilitando a expansão dos gastos sociais, especialmente em educação. Logo após a Revolução de 1949, a China priorizou a construção do Estado e o estabelecimento de um sistema de educação pública universal que contribuiu para o desenvolvimento industrial do país. $\mathrm{Na}$ Coreia do Sul, uma política deliberada de investimento em educação somada a uma melhor distribuição de renda tornou sua mão de obra altamente produtiva. Ao priorizar os recursos em educação e alcançar níveis de desigualdade inferiores aos da América Latina, os países do Leste Asiático ampliaram as oportunidades de emprego em setores tecnologicamente avançados. A capacidade estatal de tributar, portanto, foi um pré-requisito para os investimentos em conhecimento e na transformação industrial. Ademais, a distribuição de renda influenciou a alocação de ativos intermediários e, com isso, a natureza das empresas, pois disseminou habilidades técnicas e aumentou o esforço concertado na criação de empresas nacionais (Amsden, 2009; Evans, 2014; Goldenstein, 1994; Kohli, 2009).

Antes de analisar as diferentes instituições e políticas estatais, cumpre destacar as distintas experiências manufatureiras, fator decisivo para distinguir cada região dentro do "resto". Como assinala Amsden (2009), a experiência manufatureira do pré-guerra revelou-se uma condição necessária para a expansão industrial do pós-guerra, pois nenhum país retardatário bem-sucedido logrou se 
industrializar sem uma base prévia. Antes do conflito mundial, por exemplo, o Japão já estava envolvido no intercâmbio de manufaturas com seus vizinhos, o que contrastava com a divisão "colonial" do trabalho entre a América Latina e o Attântico Norte. Outra diferença marcante entre os países do "resto" que surgiu na esteira da guerra foi a extensão da propriedade estrangeira. Devido aos movimentos de descolonização e à questão geopolítica ligada à ameaça comunista, os países asiáticos foram capazes de nacionalizar ou expropriar empresas de propriedade estrangeira, abrindo caminho para a criação de grandes empresas de propriedade nacional. Em sentido oposto, os países latino-americanos, situados na área de influência dos Estados Unidos, não experimentaram a mesma ruptura na propriedade estrangeira, sendo essa uma das razóes para a relativa escassez de empresas nacionais de grande porte.

Uma das condições necessárias para a industrialização tardia foi a transferência tecnológica. Entre 1850 e 1950, quando as comunicações e o transporte eram relativamente ruins, o processo de transferência foi problemático, situação que só mudaria após a Segunda Guerra. Com o fim do conflito mundial, a empresa transnacional contribuiu para difundir tecnologia e práticas administrativas modernas no "resto". No entanto, dois modelos divergentes de desenvolvimento emergiram em cada região. No chamado modelo autônomo ou independente, adotado no Leste Asiático, as empresas líderes são de propriedade nacional, prevaleceu a decisão de criar tecnologia própria e houve limites para a entrada de empresas estrangeiras. $\mathrm{Na}$ América Latina, por sua vez, predominou um modelo de "integração" ou dependente, em que as empresas líderes são de propriedade estrangeira, pois teve mais valor a opção de "comprar" tecnologia das grandes transnacionais, que contaram com incentivos dos governos para instalar suas unidades na região (Amsden, 2009).

O grau de contribuição da empresa transnacional para o aprendizado do "resto" dependeu do timing de sua chegada e de ela ter excluído ou incluído as empresas de propriedade nacional. 
De maneira geral, quanto mais tardia a chegada da empresa transnacional, menor o efeito de exclusão e maior a possibilidade para o surgimento de uma empresa líder nacional. Para Amsden (2009), o timing da chegada das transnacionais ao "resto" dependeu da geografia e da história. Como os investimentos dessas empresas em manufatura nos países mais atrasados tendiam a ser influenciados pela distância - os Estados Unidos investiram principalmente na América Latina, e o Japão na Ásia - e como as transnacionais norte-americanas investiram no exterior antes das japonesas, a chegada de investimento estrangeiro se iniciou antes na América Latina do que na Ásia.

Ao analisar o processo de industrialização latino-americano, Celso Furtado (2007) observa que predominou, na região, menos um fenômeno de cooperação financeira do que o controle de atividades produtivas por parte de grupos que já vinham abastecendo o mercado com exportações. Por dispor do controle das marcas de fábrica conhecidas do mercado, de facilidades para mobilizar recursos técnicos e acessar o mercado de crédito, os grupos estrangeiros ocuparam posições privilegiadas nos mercados em que transcorria o processo de substituição de importações, muitas vezes com facilidades excepcionais criadas pelos governos latino-americanos. ${ }^{3}$ Por meio de uma análise histórica, Furtado (2007, p. 454-55) sintetiza bem as razões da presença da grande empresa transacional no processo de industrialização do subcontinente:

\footnotetext{
${ }^{3}$ No Brasil, o governo de transição que assumiu após o suicídio de Getúlio Vargas em 1954, de caráter liberal-conservador, incentivou a entrada de capitais estrangeiros diretos por meio da Instrução n. ${ }^{\circ} 113$ da Superintendência da Moeda e do Crédito (SUMOC), entidade responsável pela moeda até a criação do Banco Central, em 1964. Na prática, a medida estabeleceu um regime de discriminação em favor de empresas estrangeiras instaladas no país em detrimento das nacionais. Como as transnacionais tinham acesso a um câmbio favorecido, houve grande incentivo para a instalação da indústria automobilística, setor que viria a ser totalmente dominado por empresas estrangeiras. Ademais, essa medida induziu muitas empresas nacionais a se ligarem a grupos estrangeiros a fim de terem acesso às facilidades cambiais (Bresser-Pereira, 2014; Furtado, 2007).
} 
A industrialização latino-americana ainda se encontrava em seus primórdios quando se abriu para a economia internacional uma fase de importantes transformações. O sistema tradicional de divisão internacional do trabalho, baseado no intercâmbio de matérias-primas por manufaturas, entra em declínio, e tem início a descentralização da atividade industrial em escala mundial sob o controle de grandes empresas criadoras ou controladoras do progresso técnico, na forma de novos produtos e de novos processos produtivos. $\mathrm{Na}$ América Latina esse processo assume principalmente a forma de controle progressivo das atividades manufatureiras locais, nos setores em que é mais rápido o progresso tecnológico, por grandes empresas cujas sedes se encontram, na grande maioria dos casos, nos Estados Unidos.

Alguns críticos afirmam que a principal consequência da precoce entrada do investimento estrangeiro nos setores mais dinâmicos da manufatura na América Latina foi deslocar os grupos domésticos para os setores de commodities ou de serviços. Nas décadas formativas de 1950 a 1970, o fluxo de investimento estrangeiro em manufaturas tendeu a excluir empresas locais das áreas de média e alta tecnologia, com destaque para a montagem automobilística. Dessa forma, as transnacionais dominaram o estágio de montagem da produção e até mesmo a primeira camada da manufatura de peças. Em contraste com a realidade latino-americana, os governos do Leste Asiático impuseram severas condicionalidades e regulações para a instalação de grupos estrangeiros, possibilitando a criação de empresas líderes no setor automotivo. $\mathrm{O}$ processo asiático demonstra que a produção local e a estrangeira tendem a ser complementares expost, pois as empresas locais não conseguem resistir à concorrência direta ex ante. No caso coreano, grupos estrangeiros só chegaram ao país depois que uma empresa local já havia se estabelecido. Ademais, a montagem de automóveis acabou sendo uma plataforma para a formação de empresas 
nacionais, como a Hyundai Motors, na Coreia do Sul, e a Yuelong, em Taiwan (AMSDEN, 2009; SCHNEIDER, 2013).

Além da geografia e do timing histórico, a natureza dos subsídios governamentais e os padrões de desempenho foram determinantes na criação de líderes nacionais no setor automobilístico e em outras indústrias de média e alta tecnologia. Em países como Coreia do Sul e Taiwan, os padrões de desempenho foram estabelecidos para impedir que investidores estrangeiros se tornassem atores dominantes em quaisquer setores. As transnacionais tinham de se submeter a condições relacionadas à repatriação de lucros, à balança de pagamentos, aos tetos de propriedade estrangeira e ao nível do poder monopolista, medidas que desestimulavam a sua entrada. Nos casos em que não eram proibidas, as empresas estrangeiras tinham de formar joint ventures como condição para a entrada. Além disso, os investimentos diretos tinham de ser controlados para impedir que subsidiárias fossem de propriedade integralmente estrangeira. $\mathrm{Na}$ América Latina, em contraste, os controles do pós-guerra sobre os investimentos das transacionais foram fracos ou erráticos. O Brasil, por exemplo, promoveu alianças entre empresas estatais, privadas e transnacionais, mas não impôs tetos aos investimentos estrangeiros individuais. Desde o início do processo de industrialização brasileiro, alguns críticos argumentavam que o investimento estrangeiro sem controle poderia ser prejudicial ao país, devido ao ônus que implicariam no futuro as remessas de lucros e royalties (Amsden, 2009; Bresser-Pereira, 2014; Goldenstein, 1994).

As diferentes políticas adotadas geraram resultados bem diversos em cada região. Como consequência da entrada precoce do investimento estrangeiro na América Latina, as transnacionais passaram a dominar os setores de alta tecnologia, as empresas estatais restringiram-se naqueles relacionados com recursos naturais e os grupos privados locais ficaram concentrados nos segmentos de menor habilidade e tecnologia. Ao fazer um balanço da situação nas duas regiões no início do século XXI, é possível concluir que, entre as maiores empre- 
sas latino-americanas, apenas a brasileira Embraer ${ }^{4}$ pertence ao setor industrial de alta tecnologia, cenário oposto ao asiático, cujas empresas se concentram majoritariamente no setor manufatureiro de alta tecnologia. Após décadas de industrialização, países como Coreia do Sul, China e Índia possuem empresas nacionais produtoras de automóveis, diferentemente dos latino-americanos, que não constituíram nenhuma empresa nesse segmento.

Os investimentos realizados pelas transnacionais em $P \& D$ nos chamados países emergentes têm sido reduzidos, sobretudo na América Latina. Além de concentrar o setor de P\&D nas matrizes, as empresas transnacionais possuem poucos incentivos para investir em produtos ou processos inteiramente novos ou que estejam na fronteira mundial do conhecimento. Da mesma forma, conquanto invistam em aquisições, internamente ou no exterior, os grupos privados latino-americanos não alocam maciçamente recursos em P\&D, com exceções, como a Embraer. Isso ocorre porque há uma grande concentração do setor privado regional na área de commodities, que geralmente não oferece oportunidades promissoras para a expansão em P\&D. Em setores como mineração, metais básicos, cimento e papel e celulose, as empresas têm poucos incentivos para investir em inovação de produtos e criar empregos mais qualificados. Em geral, a inovação nesses setores está ligada às áreas de gestão e logística, responsáveis pelo aumento da produtividade dessas empresas. Nas antípodas do empresariado latino-americano, os

\footnotetext{
4 A Empresa Brasileira de Aeronáutica S.A. (Embraer) é resultado de um projeto bem-sucedido do governo brasileiro que remonta à década de 1940, quando o recém-criado Ministério da Aeronáutica criou o Centro Técnico Aeroespacial (CTA). Posteriormente, em 1950, o CTA fundou sua escola de engenharia, o Instituto Tecnológico de Aeronáutica (ITA). Em 1953, a criação do Instituto de Pesquisa e Desenvolvimento no âmbito do CTA reforçou a estratégia de formação de conhecimento em setores-chave da indústria aeronáutica. Em 1969, a Embraer foi criada, apoiada por gerações de engenheiros formados pelo ITA e pelo próprio CTA. Assim, graças ao apoio governamental, a Embraer tornou-se capaz de agregar capacitação tecnológica à indústria brasileira (Além e Cavalcanti, 2005). A empresa foi privatizada em 1994, durante o governo Itamar Franco.
} 
grupos privados orgânicos do Leste Asiático, concentrados no setor manufatureiro, possuem mais incentivos para investir em P\&D e, consequentemente, para contratar engenheiros e gerar mão de obra mais qualificada, a exemplo dos chaebols ${ }^{5}$ coreanos. No entanto, ao contrário do que sucede nos países desenvolvidos, os principais investimentos em $\mathrm{P} \& \mathrm{D}$, nos países do "resto", são realizados pelo Estado (Schneider, 2013).

Ao analisar os países em desenvolvimento, é impossível não mencionar o relevante papel desempenhado pelas empresas de propriedade estatal. Após a Segunda Guerra Mundial, a liderança nacional nos principais setores do "resto" foi assumida pelas empresas estatais, que se concentraram nas indústrias siderúrgicas e petroquímicas. Apesar de criticadas com o advento do neoliberalismo nos anos 1980 e 1990, os governos do "resto" apoiaram-se nas estatais durante o processo de catch up, em setores tão distintos quanto o da indústria pesada, de comunicações ou transporte. Atualmente, algumas delas estão entre as empresas mais lucrativas do mundo. $\mathrm{O}$ número de estatais entre as 100 maiores empresas da lista da Fortune "Global 500", que as classifica por receita, subiu de 11, em 2005, para 25, em 2010. Assim, uma análise dos processos de desenvolvimento dos países asiáticos e latino-americanos permite concluir que essas empresas realizaram transferências tecnológicas exemplares, fortaleceram a administração profissional, investiram fortemente em P\&D e se tornaram uma verdadeira escola de aprendizado para o pessoal técnico e os empresários que posteriormente ingressaram na indústria privada (Amsden, 2009; Musacchio e Lazzarini, 2015).

\footnotetext{
5 Os chaebols - grandes conglomerados que, ao permitirem economias de escala, reforçavam a posição competitiva da indústria coreana - foram criados com decisiva participação do Estado, que os mantinha sob controle estrito. Também contribuíram para sua formação a ajuda norte-americana e a distribuição de fábricas de propriedade japonesa nos anos 1950 (Amsden, 2009; Goldenstein, 1994). Deve-se esclarecer que o Japão ocupou a península coreana entre 1910 e 1945.
} 
A partir de 1945, os países do "resto" iniciaram um processo de industrialização tardia que provocaria a diversificação de sua base manufatureira e levaria, em alguns casos, à exportação de manufaturados de alto valor agregado. Deve-se destacar que o papel do Estado foi decisivo para o desencadeamento e a sustentação de estratégias bem-sucedidas de desenvolvimento econômico. Por meio de intervenções seletivas, combinando incentivos ao setor privado com exigências de desempenho, foi possível implementar projetos compartilhados de transformação da estrutura produtiva e de inserção inovadora no sistema capitalista internacional. Nesse sentido, a industrialização tardia tornou-se um processo de crescimento de base institucional, que dependeu do estabelecimento de mecanismos de controle, como as políticas de subsídios, os padrões de desempenho e os bancos de desenvolvimento. Em grande medida, as diferentes trajetórias do Leste Asiático e da América Latina podem ser explicadas como resultado da criação e do funcionamento dessas instituições. ${ }^{6}$

Nos países do Leste Asiático, as grandes empresas consolidaram seu poder em resposta aos incentivos governamentais que, diferentemente da experiência latino-americana, eram distribuídos em função do cumprimento de metas rígidas de desempenho. As empresas líderes obtinham incentivos para sua expansão somente se alcançassem excelente desempenho nas áreas de exportação, P\&D ou introdução de novos produtos. Portanto, a concessão de

\footnotetext{
${ }^{6}$ Amsden (2009) observa que a formação de instituições para criar mecanismos de controle funcional foi o ponto de partida para criar os vencedores e explicar os perdedores. Entre os últimos, destaca-se a Argentina. Entre os membros do "resto", o país platino alcançou o mais baixo índice de crescimento para o valor agregado das manufaturas, para os salários reais e para as exportações durante quase cinquenta anos, apesar de ter iniciado o período pós-guerra com o mais alto nível de escolaridade e a mais elevada renda per capita, além de possuir, na época, considerável experiência manufatureira. Um dos fatores que explica tal declínio está no fato de que a Argentina simplesmente não desenvolveu nenhum mecanismo de controle funcional: não sistematizou a alocação de subsídios, nem criou um banco de desenvolvimento.
} 
subsídios (ativos intermediários) foi baseada no princípio da reciprocidade. Ademais, os recipientes de subsídios tinham de seguir padrões de desempenho monitoráveis, por natureza redistributivos e concentrados nos resultados. Assim, ao selecionar e promover empresas, o governo incentivava a concorrência entre elas, garantindo acesso privilegiado a crédito barato e a subsídios àquelas que se destacassem no cumprimento das metas estabelecidas (Amsden, 2009; Goldenstein, 1994).

$\mathrm{Na}$ Coreia do Sul e em Taiwan, a política industrial e os incentivos do governo foram formulados para estimular investimentos na moderna manufatura, por meio de subsídios aos chamados "setores prioritários". Na Coreia, os incentivos eram formados por empréstimos subsidiados fornecidos pelo sistema bancário. Em Taiwan, a atuação governamental ocorreu por meio de incentivos tributários para investimentos em setores designados. Em ambos, houve proteção para as indústrias nascentes, que ficaram protegidas por restrições às importações até os anos 1980. Em alguns casos, o governo chegou a desencorajar a entrada de empresas transnacionais, objetivando garantir maior espaço para os grupos privados realizarem o aprendizado tecnológico. Além disso, nos dois países, a política industrial nunca se restringiu a subsidiar plantas industriais ou equipamentos, pois sempre estimulou os empresários locais a investirem na produção de novas tecnologias (Evans, 2014; Rodrik, 2011).

No caso do Brasil, a distribuição de subsídios foi realizada sem uma cobrança de desempenho tão severa como ocorreu na Coreia do Sul. Apesar da ampla intervenção estatal, seu caráter foi radicalmente diferente. $\mathrm{O}$ Estado brasileiro nunca conseguiu arbitrar com a mesma capacidade do Estado coreano os distintos interesses intraburguesia. Com isso, o setor privado assumiu menos riscos e jamais permitiu que a intervenção estatal comprometesse sua capacidade de acumulação. Segundo Lídia Goldenstein (1994, p. 159), "sem conseguir imputar perdas, o Estado amortecia os eventuais confli- 
tos intracapital por meio da distribuição de benesses que acabaram corroendo sua já frágil capacidade de alavancar o financiamento da economia".

A fim de acelerar o processo de desenvolvimento, os países do "resto" conceberam uma inovadora instituição centrada no Estado para mobilizar capitais: o banco de desenvolvimento, que acabou se tornando o elemento central do Estado desenvolvimentista. Na realidade, os primeiros bancos de desenvolvimento datam do século XIX e foram criados na Bélgica e na França com o intuito de financiar a construção da infraestrutura europeia. Com o declínio dos mercados privados e a escalada das intervenções estatais que se seguiram às duas guerras mundiais, houve a expansão e o reforço da importância dos bancos de desenvolvimento. Durante a reconstrução após 1945, o Plano Marshall exigiu que os países canalizassem fundos internacionais para a reconstrução por meio dos bancos de desenvolvimento, acarretando a criação do Kredintaltanlt fur Weidarufban (KfW) alemão e do Banco de Desenvolvimento do Japão (JDB). Na mesma época, surgiram bancos de desenvolvimento em alguns países do "resto", como o BNDE, no Brasil, o Banco de Desenvolvimento da Coreia (BDC), na Coreia do Sul, o Banco de Desenvolvimento Industrial, na Índia, e a Nacional Financeira (Nafinsa), no México (Amsden, 2009; Musacchio e Lazzarini, 2015). ${ }^{7}$

Os bancos de desenvolvimento financiaram mais ou menos as mesmas indústrias básicas responsáveis pelo crescimento do "resto" no imediato pós-guerra, fornecendo capital de longo prazo para projetos que não poderiam ser financiados pelo crédito privado. Os setores que

\footnotetext{
A fonte de custeio para os bancos de desenvolvimento variou em cada caso. No México, empréstimos estrangeiros financiaram seu banco; na Coreia do Sul, o BDC financiou suas atividades emitindo debêntures de finanças industriais (comprados sobretudo por outros bancos estatais) e atraindo depósitos para a poupança; já o Brasil financiou o BNDES por meio da poupança obrigatória dos trabalhadores, usando seus fundos de previdência como capital (Amsden, 2009).
} 
receberam mais recursos, tornando-se os principais mutuários, foram os metais básicos (aço e ferro), os produtos químicos (petroquímica), o maquinário (elétrico e não elétrico), os equipamentos de transporte (automóveis, navios e peças automotivas) e os produtos têxteis. Além disso, a infraestrutura foi o principal alvo dos bancos de desenvolvimento. Ao contrário da construção de ferrovias no pré-guerra, projetos como eletrificação, construção de rodovias e aeroporto, irrigação e saneamento geraram uma demanda substancial por insumos fabricados localmente. Esses investimentos fortaleceram grupos empresariais que participaram de tais projetos, a exemplo das grandes construtoras brasileiras. Assim, é inegável que os bancos de desenvolvimento transformaram os arranjos financeiros do pós-guerra, fornecendo uma alta proporção dos empréstimos de longo prazo para a indústria e a infraestrutura em quase todos os países do "resto" (Amsden, 2009).

Entre os bancos de desenvolvimento, o BNDES destaca-se por ser um dos mais antigos e maiores do mundo. Criado em 1952 como Banco Nacional de Desenvolvimento Econômico (BNDE, depois mudado para BNDES, quando se acrescentou "e social" ao nome, em 1982), o Banco tinha como objetivo fornecer crédito de longo prazo para investimentos em energia e transporte. Posteriormente, ampliou esse escopo para oferecer empréstimo a uma série de "indústrias básicas" que o governo pretendia desenvolver, como metais, petróleo, produtos químicos e cimento. Durante quarenta anos, nenhuma grande iniciativa envolvendo capital privado brasileiro foi implementada sem o apoio do BNDES, pois não havia outra fonte real e alternativa de capital de longo prazo no país. Para se ter uma ideia da atual relevância do Banco, em 2010, o valor de empréstimos desembolsados pelo BNDES equivalia a mais de três vezes a quantia fornecida pelo Banco Mundial. Além disso, o BNDES era um dos bancos mais lucrativos, em termos de retorno sobre o ativo, e um dos mais rentáveis, em termos de retorno sobre o patrimônio líquido, com exceção do KfW (Amsden, 2009; Musacchio e Lazzarini, 2015). Com o BNDES, o Brasil criou uma instituição 
burocrática com forte senso de missão institucional e capacidade técnica com competência para apoiar projetos de desenvolvimento de longo prazo.

Com a crise de 2008, os bancos de desenvolvimento ganharam novo impulso, e a Argentina e os Estados Unidos anunciaram a intenção de criar instituições semelhantes. Segundo Aldo Musacchio e Sérgio Lazzarini (2015, p. 273), uma pesquisa realizada em 2011 revelou a importância dos bancos de desenvolvimento para diversas regiões: foram identificados 288 bancos de desenvolvimento em todo o mundo, concentrados sobretudo no sul e no leste da Ásia (29,5\%), na África (24,3\%) e na América Latina e o Caribe (17,7\%). Os dados demonstram, portanto, a contínua relevância dessas instituições para as estratégias de desenvolvimento dos países retardatários.

Os bancos de desenvolvimento contribuíram para a transformação da estrutura produtiva ao submeter o setor privado a padróes de desempenho relacionados a práticas administrativas no nível da empresa (padrões técnicos) e a metas de política nacional (padrões políticos). A eficiência dos bancos de desenvolvimento dependia da disciplina e dos padrões de desempenho, cujo monitoramento estava vinculado às capacidades burocráticas dos países. Entre os padrões políticos, destacam-se as metas de exportação e os requisitos de conteúdo local. Nos países do Leste Asiático, a política industrial combinou subsídios à exportação com intensa pressão burocrática para garantir o cumprimento de metas. Com o mais elevado índice de crescimento das exportações no "resto", a Coreia do Sul induziu suas empresas a exportar, atrelando a concessão de subsídios às metas de exportação, negociadas conjuntamente pelo setor privado e pelo governo e divulgadas em reuniões mensais de alto escalão. Esse tipo de política concedeu fortes incentivos para que as empresas privadas aumentassem seu nível de produtividade, se fortalecessem e pudessem competir no mercado externo. Apesar de sua disseminação na maior parte do "resto", os padrões de desem- 
penho relativos à exportação tornaram-se mais intensos na Coreia do Sul e em Taiwan (Amsden, 2009; Rodrik, 2011).

Nos países em desenvolvimento, os padrões de desempenho relativos a requisitos de conteúdo local concentraram-se na indústria automobilística. Tais requisitos tinham por objetivo induzir as montadoras de automóveis (estrangeiras ou nacionais) a comprar suas peças e componentes de fornecedores internos em troca da concessão de proteção tarifária a veículos finalizados, de limites ao ingresso de novas montadoras e de subsídios financeiros. Com isso, os governos pretendiam criar empresas nacionais, desenvolver capacidades tecnológicas e poupar ou ganhar divisas. Mesmo nos países latino-americanos, que não criaram indústrias automotivas próprias, os efeitos das leis de conteúdo local sobre o aprendizado foram grandes, sobretudo no setor de autopeças, com o surgimento de empresas nacionais de pequena e média escala. Nos anos 1990, os requisitos de conteúdo local tornaram-se alvo de críticas da OMC. Desde então, as grandes montadoras passaram a adquirir suas peças e componentes globalmente. Essa medida atingiu especialmente os países onde as indústrias automotivas eram de propriedade estrangeira, a exemplo de Argentina, Brasil e México, levando à desnacionalização ou à quebra de muitos fornecedores de peças-chave (Amsden, 2009).

Nos estágios iniciais da industrialização tardia no pós-guerra, entre as décadas de 1950 e 1980, tanto os países latino-americanos quanto os asiáticos compartilhavam, de alguma forma, um conjunto semelhante de instituições desenvolvimentistas. Na realidade, o Leste Asiático tinha começado um pouco atrás da América Latina. Em 1975, o valor agregado das manufaturas na América Latina representava $55 \%$ do valor agregado total das manufaturas dos países em desenvolvimento, somando-se o "resto" ao "resquício". Em 1994, a participação latino-americana caíra para 35,9\%. Nesse mesmo intervalo, a parcela da produção manufatureira representada pelo sul e pelo leste da Ásia havia subido de meros 26,4\%, em 1975, para 47,9\%, vinte anos depois. Houve, portanto, uma clara divisão nas trajetórias 
do "resto" a partir dos anos 1980, quando os países do Leste Asiático atingiram níveis de desenvolvimento superiores aos da América Latina (Amsden, 2009).

Dados do Banco Mundial confirmam a divergência nas trajetórias de crescimento da América Latina e do Leste Asiático nas últimas décadas. $\mathrm{O}$ gráfico 1 mostra a evolução anual do PIB dessas duas regiões, entre 1961 e 2019. Já o gráfico 2 destaca a evolução do PIB de Brasil e Coreia no mesmo período histórico.

Gráfico 1 - Taxa de crescimento do PIB na América Latina e Leste Asiático (1961-2019)

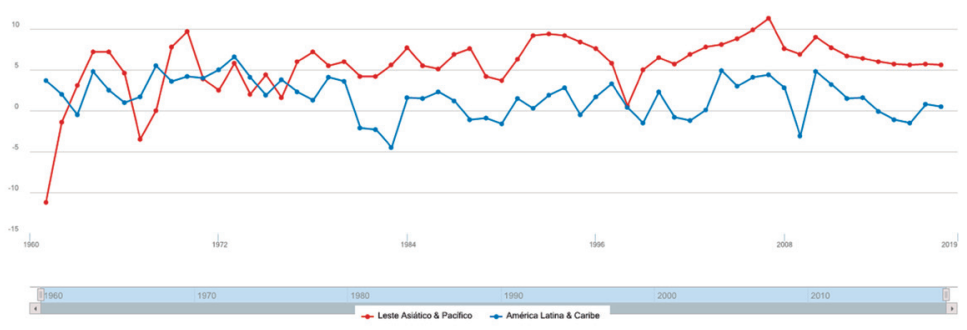

Seres: : GDP per capita groment (annual \%)

Source: Wotd Developmenting

Fonte : Banco Mundial, 2020. 
Gráfico 2 - Taxa de crescimento do PIB no Brasil e na Coreia do Sul (1961-2019)

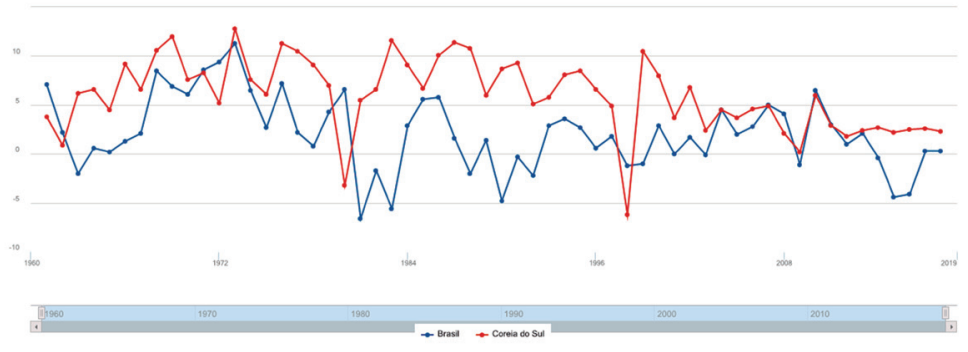

Senes: GDP per capta gromth (annual \%)

Source: World Development

Fonte : Banco Mundial, 2020.

Com a crise da dívida dos anos 1980, críticos liberais associaram o mau desempenho das economias latino-americanas ao modelo de substituição de importações. Essa estratégia de desenvolvimento possibilitou a aceleração do crescimento, especialmente entre as décadas de 1950 e 1970, quando os índices de produtividade cresceram mais rapidamente na América Latina do que no Leste Asiático (Rodrik, 2011). No entanto, ao contrário dos países asiáticos, os latino-americanos não realizaram reformas estruturais - como a agrária e a educacional -, não construíram sólidas capacidades estatais, nem lograram desenvolver setores dinâmicos da economia. Ademais, o modelo colocou pouca ênfase na habilidade das empresas domésticas em exportar e competir no mercado global. Apesar disso, o balanço da estratégia de substituição de importações é positivo, pois foi o período de mais elevado crescimento das economias latino-americanas, sobretudo quando comparado à época de hegemonia neoliberal. Como afirma Robert Boyer (2009), contrariamente à interpretação prevalecente nos anos 1990, o esgotamento do modelo substitutivo não resultou da sua não validade, mas da chegada ao limite dessa estratégia, em decorrência do seu próprio sucesso. 
Diferentemente do modelo de substituição de importações "fácil", ou "easy-ISP" (import-substituting industrialization), prevalecente na América Latina, os países do Leste Asiático adotaram o "difficult ISP" (Kohli, 2009). Após introduzir o modelo substitutivo nos anos 1950, os países asiáticos mais dinâmicos conseguiram passar para uma estratégia de exportação de produtos manufaturados ainda nos anos 1960. Quando as capacidades necessárias para aprofundar o desenvolvimento passaram a exigir mais tecnologia, uma escolha teve de ser feita: estreitar as relações com firmas estrangeiras ou investir mais na formação de empresas nacionais com tecnologia própria (Amsden, 2009; Bresser-Pereira, 2009). Além de escolher a segunda opção, os países do Leste Asiático realizaram profundas reformas agrária, educacional e tributária, limitaram a presença do investimento externo, fortaleceram as capacidades burocráticas e criaram grandes empresas líderes nacionais. Foi nesse quadro, radical e estruturalmente diferente das economias latino-americanas, que os países asiáticos enfrentaram as transformações que ocorreram no sistema capitalista internacional a partir dos anos 1980.

Em resumo, após a Segunda Guerra Mundial, os países da periferia adotaram estratégias bem-sucedidas de desenvolvimento econômico, com taxas extraordinárias de crescimento entre os anos 1950 e 1980. O papel do Estado na estruturação dos modelos de industrialização por substituição de importações foi fundamental para os processos de catch up. No entanto, dois modelos divergentes de desenvolvimento emergiram no Leste Asiático e na América Latina. Nos países asiáticos, consolidou-se um modelo de desenvolvimento nacionalista ou autônomo, caracterizado por sociedades mais igualitárias, fortes capacidades estatais e grandes empresas nacionais nos setores de alta tecnologia. Nos países latino-americanos, prevaleceu um modelo de desenvolvimento dependente, marcado por sociedades altamente desiguais, capacidades burocráticas fracas, elevada participação do capital estrangeiro na estrutura produtiva e um empresariado concentrado nos setores primários 
da economia. Assim, nos últimos anos, enquanto o Leste Asiático vem se transformando na fábrica do mundo, a América Latina - e o Brasil - tem se convertido progressivamente na fazenda do planeta.

\subsection{A expansão do capitalismo brasileiro e seus impactos na América do Sul}

Esta seção analisa o avanço do capitalismo brasileiro na região, a magnitude do investimento externo do país e os impactos causados pelas empresas brasileiras nas nações vizinhas. O Brasil foi o país latino-americano que mais se desenvolveu com o processo de industrialização por substituição de importações. Como ocorre com qualquer país capitalista que se desenvolve, houve uma internacionalização da fronteira econômica brasileira, movimento que se acentuou nos últimos anos. No entanto, a recente expansão do capitalismo brasileiro coincidiu com a chegada ao poder de um governo progressista. Apesar de o Estado e o setor privado terem, muitas vezes, interesses recíprocos e sobrepostos, ambos também possuem objetivos estratégicos distintos. Diante de um possível conflito entre a lógica empresarial e a lógica diplomática, pretende-se avaliar em que medida a internacionalização das empresas brasileiras poderá afetar a dimensão política da diplomacia do país para a América do Sul.

A relação entre Estado e capitalismo faz parte da essência e da estrutura do próprio sistema capitalista, pois um não existe sem o outro. No século XX, o aumento da intervenção do Estado na economia levou à formação do conceito de capitalismo de Estado. Musacchio e Lazzarini (2015, p. 10) definem capitalismo de Estado como "a influência difusa do governo na economia, seja mediante participação acionária minoritária ou majoritária nas empresas, seja por meio do fornecimento de crédito subsidiado e/ou de outros privilégios a negócios privados". O capitalismo de Estado atingiu o auge na década de 1970, quando a produção das estatais como 
proporção do PIB alcançou 10\% em economias mistas - como os autores se referem aos países industrializados desenvolvidos - e quase 16\% nos países em desenvolvimento. Nos anos 1980, houve várias experiências de reformas nas estatais como meio para atenuar as dificuldades dessas empresas e dos próprios Estados. Com o fim do bloco socialista e a hegemonia das ideias neoliberais, os governos acabaram privatizando milhares de empresas, abrindo suas economias e desmantelando os controles de capital. No entanto, o processo de privatização não redundou na plena desarticulação dos sistemas de capitalismo de Estado desenvolvidos no século XX. Na realidade, houve uma profunda modificação na maneira como os governos gerenciam suas grandes empresas estatais.

Atualmente, é possível identificar duas formas predominantes de capitalismo de Estado. No modelo "investidor majoritário", o Estado permanece como acionista controlador, mas as empresas estatais apresentam características de governança diferentes que possibilitam a participação de investidores privados. No modelo "investidor minoritário", o capitalismo de Estado possui uma forma mais híbrida, na qual o Estado renuncia ao controle de suas empresas em favor de investidores privados, mas continua com alguma participação acionária. Há vários canais pelos quais os Estados atuam como acionistas minoritários - por exemplo, manter diretamente ações residuais em empresas parcialmente privatizadas ou usar uma empresa holding de propriedade estatal para manter participações minoritárias em diversas empresas privadas. Ademais, os governos podem utilizar bancos de desenvolvimento, fundos soberanos e outros fundos controlados pelo Estado (como fundos de pensão e seguradoras) para emprestar ou investir em empresas privadas (Musacchio e Lazzarini, 2015).

Nos países integrantes do BRICS, é grande o número de empresas em que o governo detém participação acionária majoritária ou minoritária, usando diferentes agentes financeiros públicos. Em geral, os governos utilizam estruturas de propriedade piramidais ou 
holdings estatais para gerir sua participação em diversas empresas. $\mathrm{Na}$ China, a estatal Comissão de Supervisão e Administração de Ativos atua como holding, supervisionando mais de cem empresas autônomas e holdings. Na Rússia, a empresa de gás Gazprom é efetivamente uma pirâmide, com participação majoritária em diversos grupos. Na Índia, a Life Insurance Corporation desempenha o papel de grande holding do governo e é considerada a maior investidora ativa do mercado de ações indiano. No Brasil, os fundos de pensão estatais possuem participações acionárias minoritárias em várias empresas de capital aberto e, muitas vezes, se comportam como investidores ativos, com capacidade de influenciar a estratégia da empresa. Além disso, o BNDES Participações (BNDESPar), braço de investimentos do BNDES, criado em 1982, gerencia a maior parte dos investimentos em capital próprio da instituição (Musacchio e Lazzarini, 2015).

Entre 1930 e 1980, as ondas sucessivas de expansão industrial no Brasil somente encontram explicação levando-se em conta o papel do Estado, ora ampliando sua participação direta na economia, ora subsidiando os investimentos privados. Em poucas décadas, a industrialização brasileira avançou consideravelmente no sentido de criar um sistema industrial com um grau de diferenciação similar ao das economias industrializadas. A ação do governo orientou-se para aumentar a eficiência marginal dos investimentos, o que possibilitou aprofundar o processo de substituição de importações e criar uma classe empresarial dinâmica. Assim, a trajetória do Brasil confirma a tese de que, para ser bem-sucedida, uma estratégia de desenvolvimento demanda um Estado e um empresariado forte (Boschi, 2011; Furtado, 2007).

Durante o primeiro governo Vargas (1930-45), o Estado brasileiro aumentou sua participação na economia e fundou grandes empreendimentos, a exemplo da Companhia Siderúrgica Nacional, em 1941, e a Companhia Vale do Rio Doce, em 1942. A intervenção do governo possuía duas razões centrais. Por um lado, o Estado pre- 
tendia promover a industrialização e acelerar o desenvolvimento do país. Por outro, os mercados de ações e de créditos estavam em crise e os investidores privados não se dispunham a assumir riscos com a criação de novas empresas industriais. No entanto, demoraria até os anos 1950 para que surgisse um consenso em torno da necessidade de se apoiar um projeto nacional de industrialização.

Nos anos 1950, o capitalismo de Estado no Brasil ingressou em uma nova fase com o nacional-desenvolvimentismo, que se tornou a ideologia da industrialização e do desenvolvimento econômico e enfrentou resistências do setor liberal-conservador, o qual defendia as vantagens comparativas da economia agroexportadora. Apoiado por uma coalizão política heterogênea envolvendo empresários industriais, burocratas públicos, intelectuais e trabalhadores urbanos, o desenvolvimentismo acelerou o crescimento econômico e criou instituições centrais para o processo de desenvolvimento brasileiro, como o BNDES, em 1952, e a Petrobras, em 1953 (Bresser-Pereira, 2014; Carrillo, 2014).

O capitalismo de Estado brasileiro atingiu o auge na década de 1970. Os governos militares (1964-85) adotaram uma política industrial ativa e criaram empresas estatais com o propósito de desenvolver novas indústrias. Durante o governo Geisel (1974-79), ocorreu o ápice não apenas na criação de empresas industriais (por exemplo, alumínio, fertilizantes e petróleo), mas também de concessionárias de serviços públicos, entre as quais, as mais importantes eram as de água, saneamento e telecomunicações (uma empresa por estado da federação). Ao final da década de 1970, mais de 40\% da formação bruta de capital no Brasil vinha do setor público (Musacchio e Lazzarini, 2015).

De maneira geral, o desenvolvimentismo deixou um legado bastante complexo. Por um lado, agravou as desigualdades socioeconômicas, transformando o país em um dos mais desiguais do mundo. Quando o modelo substitutivo entrou em crise nos anos 1980, o Brasil havia ampliado sua vulnerabilidade externa e se tornado mais 
dependente da tecnologia estrangeira em setores-chave da produção industrial. Por outro lado, o velho desenvolvimentismo modificou profundamente a estrutura produtiva brasileira. A ação estatal foi indispensável para criar a indústria automobilística, aeroespacial e de telecomunicações. Ademais, a diversificação da agricultura permitiu ao país reduzir a importação de alimentos e se tornar líder mundial na produção e na exportação agrícola. Assim, os setores implantados durante o período desenvolvimentista são, ainda hoje, extremamente importantes para a economia do país (Carrillo, 2014).

Nos anos 1990, o processo de privatização mudou a face do capitalismo de Estado no Brasil. Diferentemente de outros modelos de liberalização, o Estado conservou maneiras de reter o controle ou de influenciar as empresas estatais privatizadas. O BNDES atuou como protagonista das reformas de mercado em pelo menos três esferas: planejamento e execução das privatizações; financiamento dos adquirentes; e compra de participações minoritárias em diversas ex-estatais. Esse último caso significou a ascensão de uma nova forma de propriedade estatal minoritária de empresas, por meio da compra de participação acionária pelo BNDES via BNDESPar. Em algumas empresas, como a Embraer e a Vale, o governo manteve uma participação (golden share) que lhe garantiu o poder de veto em relação a algumas decisóes, a exemplo de mudanças na estrutura da propriedade. Em outros casos, o BNDES juntou-se a grupos empresariais para comprar ações que possibilitassem o controle das empresas privatizadas pelo governo. Ademais, os fundos de pensão públicos também investiram pesadamente na participação em companhias privatizadas (Musacchio e Lazzarini, 2015; Schneider, 2013).

Com a ascensão do PT, muitos analistas consideram que o governo brasileiro adotou um modelo neodesenvolvimentista, sobretudo a partir do segundo mandato de Lula (2007-10) e durante o primeiro governo Dilma (2011-14). Para alguns críticos, o neodesenvolvimentismo é um modelo ainda em formação que propõe a construção de um espaço de coordenação entre as esferas pública 
e privada. O novo desenvolvimentismo é conceituado como uma estratégia de desenvolvimento para os países de renda média, no ambiente competitivo da globalização, que tem como base teórica a macroeconomia estruturalista e keynesiana do desenvolvimento. Entre os elementos essenciais do neodesenvolvimentismo, destacam-se a intervenção moderada do Estado na economia, a manutenção de uma taxa de câmbio competitiva e uma ativa política social (Boschi, 2011; Bresser-Pereira, 2014).

No entanto, muitos críticos questionam se os governos progressistas efetivamente adotaram um novo modelo de desenvolvimento e em que medida este se diferencia do neoliberalismo. Ao conjugar políticas distributivas com câmbio valorizado, os governos Lula e Dilma teriam adotado um modelo social-desenvolvimentista, e não um modelo neodesenvolvimentista (Bresser-Pereira, 2014). Para alguns analistas, o neodesenvolvimentismo suavizou as contradições do neoliberalismo, e ambos seriam apenas metamorfoses da expansão contemporânea do capitalismo brasileiro (Castelo, 2014; Fontes, 2013). Para outros, o neodesenvolvimentismo apoiou-se em elementos conjunturais, desconsiderando atributos estruturais que caracterizam um padrão de desenvolvimento. Nesse sentido, o novo modelo de desenvolvimento não teria conseguido superar a histórica dependência e vulnerabilidade da economia brasileira, característica compartilhada por outros países latino-americanos (Berringer, 2013; Filgueiras, 2014). Por fim, Ian Carrillo (2014) afirma que as múltiplas contradições da trajetória do Brasil tornam problemática a afirmação de que o país adotou uma política neodensenvolvimentista nos últimos anos. Entre outras razões, isso ocorre porque os capitais públicos e privados continuaram sendo absorvidos pelos setores produtivos tradicionais, sem maior agregação de valor. Ao financiar setores primários em detrimento dos de alta tecnologia, o BNDES enfraqueceu o potencial do neodesenvolvimentismo e reforçou a dependência da trajetória vinculada ao modelo primário-exportador. Além disso, a inserção internacional 
brasileira baseou-se na demanda global por commodities, cujo ciclo de alta chegou ao fim, demonstrando a fragilidade do propalado novo modelo de desenvolvimento.

Desde 2013, a política econômica do governo começou a mostrar seus limites. No governo Lula, houve uma enorme apreciação cambial, que inviabilizou as exportações de manufaturados e agravou o processo de desindustrialização. Os efeitos desastrosos do câmbio valorizado viriam a ocorrer no governo Dilma, quando o aumento do mercado interno foi afinal capturado pelas importações. Nessa administração, houve a tentativa de compensar a moeda apreciada com uma agressiva política industrial, que envolveu redução de impostos e desoneração de encargos trabalhistas. Apesar do elevado custo para o Tesouro, a política não surtiu efeito, pois a moeda continuou valorizada. Além disso, como afirma Bresser-Pereira (2014), a presidente contou apenas com um tímido e contraditório apoio dos empresários industriais que, na medida em que deixavam de ser industriais e se convertiam em montadores (indústria maquiladora), perdiam o interesse em um câmbio competitivo, transformando-se, na prática, em importadores.

Historicamente, o BNDES exerceu um papel fundamental na consolidação do capitalismo brasileiro. Nos últimos sessenta anos, o Banco participou de todas as fases do desenvolvimento do país: o desenvolvimentismo, o neoliberalismo e o novo ensaio desenvolvimentista. Criado em fevereiro de 1952 como uma autarquia autônoma, o BNDE serviu de base para o planejamento econômico e o financiamento dos investimentos necessários à infraestrutura e à industrialização. O Banco também se tornou uma das bases da autonomia e do poder da burocracia pública brasileira. Durante a primeira década de operação, o BNDE se concentrou no financiamento de longo prazo para a renovação do sistema ferroviário e para a construção de novas usinas hidrelétricas. Entre o final das décadas de 1950 e 1960, o Banco deslocou os seus fundos para a siderurgia, transformando o Brasil em um produtor autossuficiente e, posteriormente, num grande expor- 
tador de produtos de aço. Sob o governo militar, o BNDE começou a financiar os setores de bens de capital e de produtos químicos e petroquímicos. Nesse período, o financiamento, antes voltado para empresas públicas, passou a ser direcionado para o setor privado, que deveria seguir os planos de desenvolvimento do governo. Nos anos 1980, o já então BNDES criou um braço de investimento, o BNDESPar. Ademais, o Banco mudou sua estratégia de financiamento, diminuindo os empréstimos e passando a investir mais na compra de ações (Amsden, 2009; Bresser-Pereira, 2014; Musacchio e Lazzarini, 2015).

Após atuar no processo de privatização, o BNDES mais do que triplicou seus empréstimos na primeira década do século XXI. Durante o governo Lula, o Banco se envolveu em várias operações de grande escala e ajudou a coordenar fusões e aquisições de empresas no país e no exterior, no intuito de construir os chamados "campeões nacionais" - grupos empresariais que deveriam se tornar líderes em seu setor no cenário internacional. Em geral, foram privilegiadas as áreas ligadas ao setor primário: agropecuária, mineração, papel e celulose e petróleo. Alguns críticos dessa política industrial alegam sua falta de transparência. O BNDES também é criticado por financiar fusões em setores de baixa capacidade tecnológica, incapazes de promover a transformação produtiva necessária para superar a vulnerabilidade estrutural do país. Um exemplo dessa política ocorreu com a JBS Friboi, convertida pelo BNDES em “campeã nacional". Ao investir US\$ 4 bilhões, o Banco viabilizou a aquisição da Swift Armour e da Pilgrim's Pride, tradicionais processadores de carne argentina e estadunidense. Além disso, o BNDES passou a controlar cerca de $30 \%$ do capital acionário da nova empresa. Com isso, a JBS Friboi saiu da 58. ${ }^{\text {a }}$ posição, no início dos anos 2000, para se tornar líder na produção mundial de carnes no final da década (Carrillo, 2014; Klein, 2013; Musacchio e Lazzarini, 2015; Schneider, 2013).

Nos últimos anos, o Estado brasileiro, via BNDES, financiou um processo de centralização de capitais, fortalecendo os grandes 
grupos econômicos nacionais e promovendo sua internacionalização. Ao fomentar a concentração econômica doméstica e a internacionalização das empresas brasileiras, o governo transformou o BNDES em um importante instrumento da sua política desenvolvimentista e da política exterior. Nesse sentido, as fusões e aquisições permitiram a grupos econômicos brasileiros capturar expressivos segmentos dos mercados nacional e internacional. Deve-se destacar, entretanto, que o recente movimento de expansão da fronteira econômica envolve não apenas o Brasil, mas também outros países em desenvolvimento, que passaram a ter empresas classificadas entre as grandes transnacionais.

Segundo a CNI (2013), ocorreram dois ciclos de internacionalização de empresas de países em desenvolvimento nas últimas décadas. O primeiro, nos anos 1990, teve como eixo dinâmico grupos oriundos de Coreia do Sul, Cingapura, Honk Kong e Taiwan. O segundo, na década de 2000, foi liderado por países como Brasil, Chile, México, China, Índia, Malásia e Tailândia. Para se ter uma ideia da magnitude dos ciclos, em 2003, os investimentos externos diretos (IED) das economias em desenvolvimento representavam somente 10\% do total mundial; já em 2013, essa cifra alcançou 39\%, como mostra o gráfico 3. Essa tendência se acentuou graças à crise financeira de 2008, que afetou com mais força as economias desenvolvidas. Além disso, entre 2004 e 2013, o número de transnacionais de economias em desenvolvimento incluídas entre as 2.000 maiores do mundo, segundo ranking publicado pela Forbes, subiu de 333 para 636 empresas, a maioria oriunda do BRICS. Houve, portanto, uma reconfiguração dos deslocamentos de capitais, que já não se limitam às direções Norte-Norte e Norte-Sul, pois incluem investimentos Sul-Sul e Sul-Norte, tornando mais complexas as relações centro-periferia (CEPAL, 2014; CNI, 2013; Fontes, 2013). 
Gráfico 3 - Economias desenvolvidas e em desenvolvimento: participação nos fluxos mundiais de saída de investimento externo direto, 1999-2013

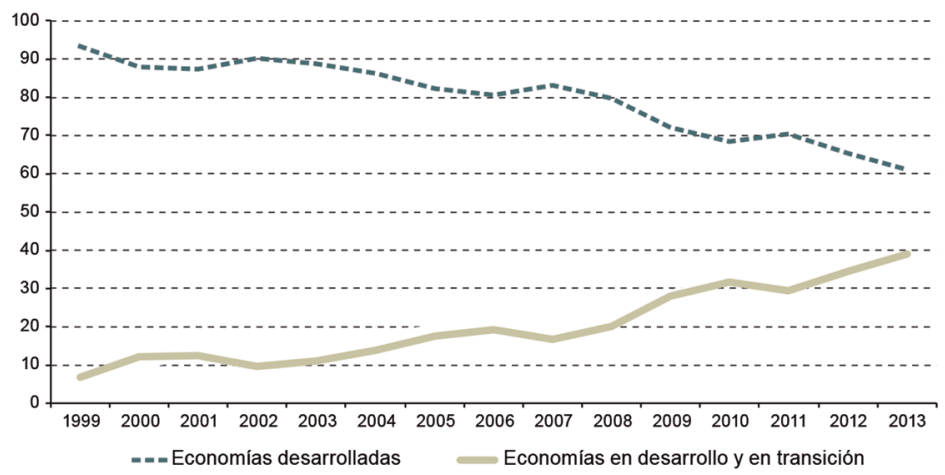

Fonte: CEPAL, 2014.

O investimento externo costuma ser uma etapa da internacionalização que se segue à exportação, principalmente no que diz respeito às empresas transnacionais dos países em desenvolvimento. Em geral, são quatro os objetivos dos investimentos externos: acesso a mercados (market-seeking), acesso a ativos estratégicos (asset-seeking), acesso a recursos naturais (resource-seeking) e busca de eficiência (efficiency-seeking). A estratégia de manter ou ampliar o acesso a mercados externos parece ser o principal objetivo perseguido pelas empresas brasileiras ao se internacionalizarem em termos produtivos. De fato, a busca pelo acesso ao mercado doméstico em que se investe é pretendida por parte considerável das transnacionais brasileiras de bens intermediários, de capital e de consumo. Já pela lógica do asset-seeking, o investidor busca acessar ativos estratégicos tangíveis e intangíveis, como conhecimentos, tecnologias, direitos de propriedade intelectual, que sejam passíveis de aquisição em determinado país. Isso explica a preferência das empresas de setores intensivos em tecnologias pelos mercados dos países desenvolvidos. 
A internacionalização produtiva também pode ser motivada pelo acesso a recursos naturais inexistentes no país de origem. Nesses casos, a localização da produção depende da geografia da disponibilidade dos ditos recursos. Por fim, as estratégias efficiency-seeking buscam o aumento da eficiência e da produtividade global das empresas mediante investimentos externos que garantam suporte à fragmentação internacional da produção e gerem ganhos de escala e escopo associados à especialização das plantas em diferentes países. Essa estratégia é típica de setores como o automobilístico e o eletroeletrônico, pouco relevantes na experiência brasileira (Além e Cavalcanti, 2005; CNI, 2013).

As estratégias de internacionalização variam conforme a região. Na Ásia, grupos empresariais orgânicos de alta tecnologia são motivados por estratégias de aumento de eficiência (efficiency-seeking). Na América Latina, em contraste, os investimentos visam majoritariamente à aquisição de competidores nos mercados estrangeiros (market-seeking). Em relação aos fatores de impulsão, o investimento externo asiático é motivado pela escassez de recursos naturais e necessidade de reduzir custos de produção e adquirir ativos estratégicos. Já o investimento externo latino-americano é determinado pela necessidade de diversificar o risco e pela pressão causada pelas políticas de liberalização. Em relação aos fatores de atração, a experiência da Ásia está centrada no acesso a mercados para implantar plataformas de exportação, na disponibilidade de tecnologia, em medidas para reduzir custos de produção e na conversão de marcas nacionais em globais. Por outro lado, na América Latina, os investimentos externos são motivados pelas redes étnico-culturais (imigrantes latinos nos Estados Unidos), por oportunidades resultantes da privatização nos países vizinhos, por acordos de comércio na região e pela conversão de marcas nacionais em regionais (CEPAL, 2014; Schneider, 2013).

As empresas transnacionais latino-americanas são conhecidas como translatinas e estão concentradas nos setores de serviços (comér- 
cio varejista e telecomunicações), recursos naturais (hidrocarbonetos e mineração) ou manufaturas intensivas em capital (siderurgia e indústria de cimento); poucas atuam nos setores manufatureiros intensivos em tecnologia. Em termos cronológicos, Brasil e Argentina foram pioneiros nos fluxos de investimentos no exterior, seguidos por Chile e México. Em relação ao destino geográfico, os investimentos das translatinas concentram-se na própria região e assumem a modalidade brownfield, envolvendo aquisições ou fusões com empresas dos países vizinhos. As maiores economias regionais têm um perfil de internacionalização mais diversificado. A empresa mexicana de cimento Cemex, por exemplo, possui investimentos na Austrália; já a brasileira Vale tem atuação em mercados da América do Norte, como demonstrou a compra da mineradora canadense Inco Ltda. As empresas brasileiras possuem investimentos na UE e são praticamente as únicas latino-americanas a investir na África. Apesar das translatinas terem uma presença mais limitada na Ásia, as brasileiras Embraer e Marco Polo realizaram grandes investimentos novos (greenfield) na China (CEPAL, 2014; Schneider, 2013). ${ }^{8}$

Segundo a CEPAL (2014, p. 81), entre as cinquenta maiores translatinas, em 2012, destacavam-se as procedentes do México (16), do Brasil (14) e do Chile (11), que eram seguidas com certa distância pela Colômbia (6), Argentina (2) e Venezuela (1). Em termos de volume de vendas, as empresas brasileiras e mexicanas eram responsáveis por $37 \%$ e $31 \%$, respectivamente, do total de vendas entre essas cinquenta empresas. Ao contrário do que afirmam alguns críticos, que denunciam o expansionismo do capitalismo brasileiro, os números mostram que a existência de grandes grupos empresariais e sua internacionalização não é um fenômeno exclusivo do Brasil na América Latina.

8 O investimento externo direto (IED) pode assumir as seguintes modalidades: instalação de subsidiária ou unidade produtiva (greenfield); formação de parceria com empresa do país no qual se investe (joint venture); e aquisição ou fusão com empresa estrangeira (brownfield) (Fonseca, 2014). 
Ainda de acordo com a CEPAL (2014), entre 2000 e 2012, as vendas das 500 maiores translatinas triplicaram, impulsionadas pelos altos preços das matérias primas e pela demanda chinesa. Esse crescimento também foi liderado por empresas do Brasil e do México e esteve concentrado nos setores de recursos naturais e serviços, como mostra o gráfico 4 .

Gráfico 4-Translatinas: concentração por setor econômico, 2005 e 2012

C. Por sector económico, 2005 y 2012

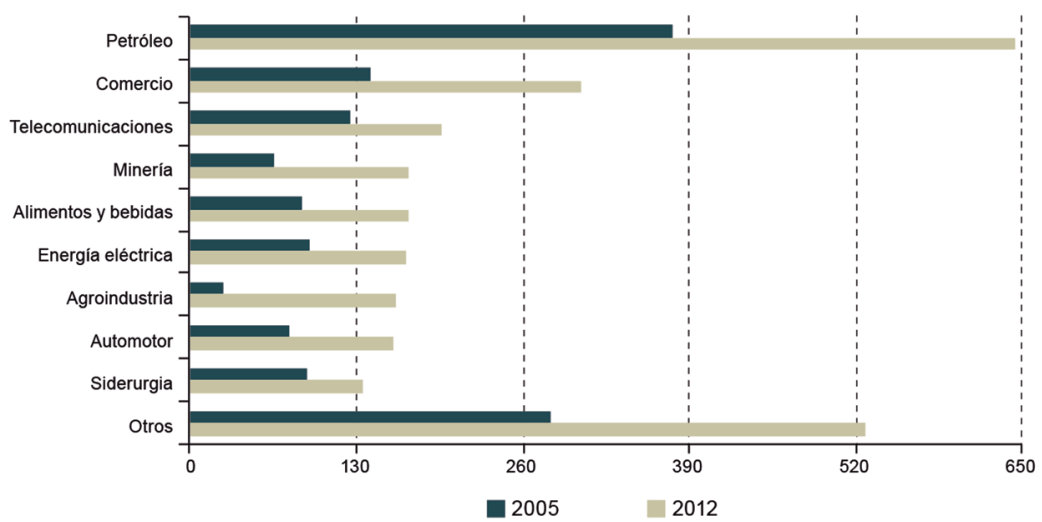

Fonte: CEPAL, 2014.

Historicamente, o Brasil sempre foi um importante receptor de investimentos externos. Na primeira década do século XXI, houve um crescimento dos investimentos de empresas brasileiras no exterior. Esse movimento não é novo e já tem mais de quarenta anos. A primeira fase do investimento de empresas brasileiras no exterior ocorreu no final dos anos 1960 e foi até 1982 - processo basicamente concentrado na Petrobras, em instituições financeiras e em grandes construtoras. Na década de 1980, observou-se uma redução dos investimentos devido à crise econômica. Ainda assim, algumas empresas, 
como a Vale e as construtoras, buscaram compensar essa tendência com a diversificação de suas carteiras de negócios, sobretudo investindo nos mercados de países em desenvolvimento (Além e Cavalcanti, 2005; CEPAL, 2014; CNI, 2013; Motta Veiga e Ríos, 2014).

Nos anos 1990, o processo de abertura econômica levou à concentração de capitais e forçou as empresas brasileiras a tornarem-se mais competitivas, para que mantivessem o mercado interno e expandissem seus negócios no exterior. Após um período de inibição nos anos subsequentes à implantação do Plano Real, o processo de integração regional provocou um aumento dos investimentos nos países do Mercosul. Em entrevista concedida na CNI, Soraya Rosar (2015) destacou o papel do bloco sul-americano no processo de internacionalização das empresas brasileiras, sobretudo na década de 1990 . Entre 2001 e 2011, o estoque de investimentos no exterior multiplicou-se por quatro. $\mathrm{O}$ crescimento acelerou-se a partir de 2004 e atingiu um máximo histórico em 2006. Recentemente observou-se uma redução do investimento brasileiro, que ficou negativo em alguns anos. Ao contrário das translatinas chilenas, colombianas ou mexicanas, as empresas brasileiras não estão acelerando seus investimentos no exterior. Apesar da expansão na primeira década do século XXI, o Brasil ainda pode ser considerado um ator secundário entre os emissores de investimentos internacionais, inclusive entre os países em desenvolvimento (Além e Cavalcanti, 2005; CEPAL, 2014; CNI, 2013).

O processo de internacionalização das empresas brasileiras envolve firmas dos mais diversos tamanhos - grandes e médias - de múltiplos setores. Isso significa que uma gama de grupos empresariais possui vantagens competitivas que lhes permite concorrer no mercado internacional, utilizando tal situação com o objetivo de aumentar e consolidar o poder de mercado da empresa. No setor de recursos naturais, além da Vale e da Petrobras, destacam-se quatro empresas agroindustriais especializadas na produção de carne, que tiveram notável expansão a partir de 2005: JBS Friboi, Marfrig, Minerva e BRF, antiga Brasil 
Foods. As duas primeiras realizaram grandes aquisições nos Estados Unidos e em outros mercados, o que as converteu em primeira e quarta produtoras mundiais de carne, respectivamente. Já a Minerva e a BRF concentraram sua expansão em países vizinhos, como a Argentina e o Uruguai (Carvalho e Sennes, 2009; CEPAL, 2014).

Outro importante grupo de empresas brasileiras está concentrado em setores industriais intensivos em capital e em recursos naturais, como a siderurgia. Nesse setor, sobressai-se a Gerdau, empresa com alto grau de internacionalização, que tem como alvo a América Latina. A Companhia Siderúrgica Nacional também possui investimentos no exterior, com ênfase nos mercados europeu e estadunidense. A Votorantim é outro conglomerado do setor siderúrgico e de cimentos que atua no estrangeiro. $\mathrm{Na}$ área de serviços financeiros, destacam-se o Banco do Brasil e o Itaú, sendo que o último tem uma estratégia de expansão centrada na América Latina. Em relação aos serviços de engenharia e construção, o Brasil possui grandes empresas atuando em diferentes partes do mundo, como a Andrade Gutierrez, a Camargo Correia, a OAS e a Odebrecht. Ao concentrar suas atividades na região, a América do Sul tem sido responsável por parte considerável do faturamento desses grupos (Carvalho e Sennes, 2009; CEPAL, 2014).?

Entre as maiores transnacionais brasileiras, a Embraer e a Marcopolo constituem exceções, visto que não atuam na área de recursos naturais, e sim no setor manufatureiro intensivo em tecnologia. A Embraer é uma empresa orientada para a exportação (somente $14 \%$ de suas receitas se originam no país) e possui centros de produção nos Estados Unidos, na China e em Portugal. Ape-

\footnotetext{
9 Enquanto escrevia a tese, ainda não era possível avaliar o impacto que a Operação Lava Jato - deflagrada pela Justiça Federal, pelo Ministério Público Federal e pela Polícia Federal - teria sobre as atividades das grandes empreiteiras brasileiras. Posteriormente, verificou-se que a seletividade da operação e os seus vínculos com os grandes meios de comunicação foram fundamentais na derrubada da presidenta Dilma. Ademais, ao desarticular o setor de engenharia nacional, a Lava Jato afetou também as ações diplomáticas relacionadas à pauta neodesenvolvimentista.
} 
sar de destinar $89 \%$ de sua produção para o mercado brasileiro, a Marcopolo também possui forte presença no exterior, com atividades manufatureiras na África do Sul, na Austrália e no México, e, em associação com empresas locais, na Argentina, no Canadá, na Colômbia, no Egito e na Índia (CEPAL, 2014).

Ao fazer um rápido balanço da atuação das transnacionais brasileiras no exterior, constata-se a elevada concentração das empresas na área de commodities. Para alguns críticos, entre 2000 e 2011 ocorreu uma nítida reprimarização da pauta exportadora. Nesse sentido, o crescimento dos grupos empresariais ligados a atividades extrativistas vem contribuindo para tornar o Brasil mais uma vez dependente dos setores agrícola e mineral. Além disso, as firmas internacionalizadas estariam relutantes em repatriar os excedentes obtidos no exterior. Segundo Carrillo (2014), tal relutância viola as relações esperadas entre Estado e mercado dentro do modelo neodesenvolvimentista. Para outros analistas, as empresas brasileiras quebraram o precedente histórico segundo o qual o setor de commodities não investiria em P\&D. Para Schneider (2013), várias firmas do país romperam com esse padrão ao investirem em P\&D e, consequentemente, gerarem empregos mais qualificados.

Uma característica especial do investimento externo brasileiro tem sido o respaldo estatal dado pelo BNDES. Entre os países latino-americanos, o Brasil é o único que conta com suporte institucionalizado. Em meados de 2002, a diretoria do BNDES aprovou diretrizes com o objetivo de criar mecanismos para estimular a inserção e o fortalecimento de empresas brasileiras no mercado internacional. Em seguida, foi alterado o Estatuto do Banco, autorizando o financiamento de empreendimentos no exterior, desde que resultassem no estímulo à exportação de produtos brasileiros. Os recursos para fomentar a internacionalização contam com o apoio de outros órgãos públicos, e aumentaram desde 2005, especialmente após a ascensão de Luciano Coutinho à presidência do Banco, em 2007. Entre os instrumentos de apoio oficial à expansão das transnacionais brasileiras, 
destacam-se: o Seguro de Crédito à Exportação (SBCE); as linhas de financiamento às exportações de bens e serviços, como o PROEX BB e o BNDES-EXIM; o apoio financeiro à internacionalização, como o BNDES-FINEM; e as capitalizações feitas pelo BNDESPar. Ademais, o BNDES abriu, em Londres, uma subsidiária em 2009, a BNDES Limited, objetivando a participação acionária em outras firmas e com a função de captar recursos no mercado financeiro para emprestar às empresas brasileiras diretamente do exterior, sem que esses recursos sejam repatriados ao Brasil. No mesmo ano, o Banco abriu um escritório no Uruguai, com o objetivo de aportar recursos diretamente nos projetos de integração regional (Além e Cavalcanti, 2005; CEPAL, 2014; Fonseca, 2014; Fontes, 2013; Schneider, 2013).

No entanto, há controvérsias quanto à magnitude do apoio estatal à internacionalização de empresas. Para Soraya Rosar (2015), ainda que o BNDES seja fundamental nos empréstimos de longo prazo, o financiamento privado costuma ser preponderante nas operações de curto prazo e nas exportações. Nesse sentido, Rosar destacou uma característica pouco conhecida do investimento externo brasileiro: muitas empresas de médio porte, sobretudo na área de tecnologia da informação, realizam investimento no exterior com capital próprio. Nesses casos, o impulso para a internacionalização constitui uma alternativa de sobrevivência para empresa diante da ameaça de ser absorvida por uma grande transnacional. Para outros analistas, muitos serviços e soluções financeiras para as operações internacionais das empresas brasileiras têm sido supridas por bancos estrangeiros. De um lado, as fontes privadas de financiamento nos mercados internacionais são responsáveis pelo baixo grau de utilização da linha de internacionalização de empresas do BNDES. De outro, há críticas relativas à inadequação dos procedimentos de análise de crédito do Banco para operações de aquisição, que é a principal modalidade de internacionalização das firmas brasileiras. Seria necessário adequar os procedimentos e reduzir os tempos de análise dos pedidos de financiamento. Assim, a maioria dos investimentos produtivos de trans- 
nacionais brasileiras realiza-se com recursos das próprias empresas ou por meio de financiamentos oriundos do setor privado. São poucas as operações que contaram nos últimos anos com o apoio oficial, a exemplo da compra da Swift Armour pela JBS Friboi, que se deu por meio de financiamento do Programa BNDES-FINEM (Carvalho e Sennes, 2009; CNI, 2013; Fonseca, 2014).

A tentativa de mapear os investimentos externos diretos do Brasil encontra dois grandes obstáculos: os paraísos fiscais (centros financeiros offshore) e as Sociedades com Propósito Específico (Special Purpose Entities - SPE). Estas são entidades estabelecidas para um objetivo específico (administração, gestão de risco cambial, facilitação de financiamento do investimento) ou uma estrutura específica (boldings) e tendem a se estabelecer em países com benefícios fiscais e baixa tributação. Algumas empresas recorrem a esses mecanismos para obter vantagens fiscais e driblar controles. Todavia, esses dois expedientes interferem nas estatísticas do Banco Central do Brasil, causando uma discrepância entre os destinos dos fluxos financeiros e o destino final do investimento, pois os dados oficiais dizem respeito ao setor e ao destino geográfico da "empresa investida imediata", e não da empresa que é a beneficiária última do investimento. Isso provoca um duplo viés com a superestimação do setor de serviços (financeiros e serviços prestados às empresas) e dos países que abrigam paraísos fiscais ou SPE (CNI, 2013; Motta Veiga e Ríos, 2014). ${ }^{10}$

Devido ao viés existente nos dados relativos ao destino dos investimentos externos, alguns trabalhos buscam mitigar o problema reunindo informações sobre a localização geográfica das unidades

${ }^{10}$ A dimensão do problema pode ser exemplificada pelos dados do Banco Central de 2012. Naquele ano, $32,2 \%$ do estoque de investimento direto no exterior foram direcionados a paraísos fiscais e outros $42 \%$ a cinco países europeus hospedeiros de SPE, com destaque para a Áustria (23\%), Países Baixos $(11,4 \%)$ e Luxemburgo (6\%). Excluindo-se esses países que representaram quase três quartos do estoque de investimentos brasileiros no exterior, os principais mercados de destino em 2012 foram: Estados Unidos (7,4\%); Espanha (6,2\%) e Argentina (2,2\%) (CNI, 2013; Motta Veiga e Rios, 2014). 
das empresas no exterior. A Fundação Dom Cabral (FDC), por exemplo, publica anualmente rankings das maiores transnacionais brasileiras com dados sobre a distribuição de unidades dessas empresas por país. A tabela 6, por exemplo, apresenta o resultado do ranking da FDC de 2014, e pode-se observar que a maior parte das empresas pesquisadas está instalada nos Estados Unidos; dos treze países da tabela, oito são da América do Sul, e o país fora das Américas que mais recebe empresas brasileiras é a China.

Em relação à dispersão geográfica, observa-se que a América do Sul concentra a maioria das empresas brasileiras: aproximadamente $75 \%$ das transnacionais possuem presença física no subcontinente; na sequência, vem a América do Norte, com cerca de 67\%, a maior parte instalada nos Estados Unidos. Segundo Soraya Rosar (2015), as empresas brasileiras costumam iniciar seu processo de internacionalização pela América do Sul, antes de partirem para os mercados mais desenvolvidos. O gráfico 5 mostra a distribuição mundial das franquias ou subsidiárias das empresas brasileiras por região. Embora haja uma predominância das empresas no entorno, não existe uma enorme discrepância entre tal presença e a que ocorre em outras regiões. Os dados, portanto, questionam a tese de que existiria uma expansão sem precedentes dos grupos empresariais brasileiros na América do Sul. Isso não significa, entretanto, que essa presença não seja forte ou não possa causar conflitos entre o Brasil e os países vizinhos.

Tabela 6 - Países com maior presença de empresas brasileiras em 2014

\begin{tabular}{clc}
\hline Posição & País & Número de empresas \\
\hline $\mathbf{1}$ & Estados Unidos & 39 \\
$\mathbf{2}$ & Argentina & 33 \\
$\mathbf{3}$ & Chile & 28 \\
$\mathbf{4}$ & Uruguai & 24 \\
$\mathbf{5}$ & Colômbia & 23
\end{tabular}




\begin{tabular}{lll}
$\mathbf{5}$ & Peru & 23 \\
$\mathbf{6}$ & México & 22 \\
$\mathbf{7}$ & China & 19 \\
$\mathbf{8}$ & Venezuela & 16 \\
$\mathbf{9}$ & Paraguai & 15 \\
$\mathbf{9}$ & Portugal & 15 \\
$\mathbf{1 0}$ & Bolívia & 14 \\
$\mathbf{1 0}$ & Reino Unido & 14 \\
\hline
\end{tabular}

Fonte: Fundação Dom Cabral, 2014.

Gráfico 5 - Percentual das empresas brasileiras que possuem subsidiárias ou franquias no mundo, 2014

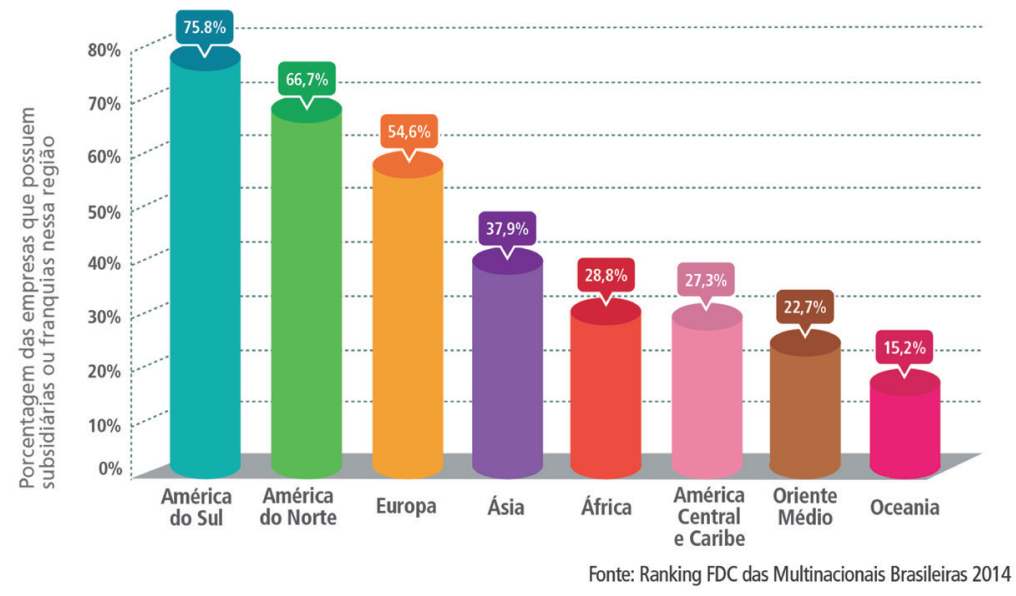

Fonte: Fundação Dom Cabral, 2014.

A presença econômica do Brasil na América do Sul ganhou novo impulso durante o governo Lula e tornou-se uma das principais dimensões de sua política externa. A combinação de uma diplomacia proativa com o apoio oferecido pelo BNDES ao finan- 
ciamento de aquisições de empresas, de exportações de bens e serviços e de grandes obras de infraestrutura nos países vizinhos permitiu uma imediata projeção regional do modelo neodesenvolvimentista adotado pelo país nos anos recentes. Por um lado, esse movimento de expansão abriu oportunidades a projetos conjuntos e diversificou a agenda de interações. Por outro, trouxe consigo uma nova onda de desigualdades no âmbito econômico e comercial, com reflexos na agenda político-diplomática. Isso significa que os interesses comerciais não traduzem facilmente, de maneira ordenada ou completa, o comportamento da política externa (Hirst, 2013; Tussie, 2013).

Alguns críticos apontam que a ascensão do Brasil à condição de exportador de manufaturados contribuiu para diferenciar o país dos vizinhos e aprofundar a especialização produtiva regional. Recentemente, dois fatores contribuíram para reforçar a divisão regional do trabalho. De um lado, o ciclo de alta das exportações de produtos básicos para mercados asiáticos, especialmente para a China. Do outro, a ampliação dos mercados domésticos, propiciada pelas políticas distributivas executadas pelos governos progressistas sul-americanos. A combinação desses fatores gerou um padrão de especialização intersetorial, no qual os países provedores de commodities para os mercados extrarregionais se tornaram os principais importadores de manufaturados brasileiros. Nesse cenário marcado por assimetrias, os países vizinhos passaram a acumular déficits comerciais de difícil reversão com o Brasil (Hirst, 2013; Luce, 2013). Os impactos negativos dessa realidade vêm sendo parcialmente atenuados por meio da cooperação horizontal (projetos nas áreas de educação, ciência e tecnologia, saúde, meio ambiente) e de fóruns de coordenação política, como a Unasul.

Outros analistas afirmam que o Brasil não é o único a expandir a sua fronteira econômica, pois o expansionismo de empresas latino-americanas não se restringe ao país. Para João Carlos Parkinson (2014), há também o movimento inverso. Segundo ele, com o crescimento da economia brasileira, empresas de outros países da 
região passaram a investir no Brasil. A expansão da renda e a criação de um mercado de consumo de massas fizeram com que empresas argentinas e chilenas enxergassem, no mercado brasileiro, maior estabilidade e dinamismo. O Chile tem feito incursões em investimentos intrarregionais em diferentes setores, como os de serviços de varejo e transporte aéreo. Segundo a CEPAL (2014), entre as principais empresas chilenas do comércio varejista destacam-se a Cencosud, a Falabella e a Ripley. No setor aéreo, destaca-se a criação da Latam, resultante da fusão da LAN Airlines com a brasileira TAM em 2012.

Diferentes levantamentos indicam que a América do Sul tem concentrado historicamente a maior parte das operações de investimento direto e financiamento oriundos do Brasil, pois a região é a que mais concentra subsidiárias de transnacionais brasileiras. Em relação às modalidades de investimento, observa-se uma preferência pela internacionalização por meio de operações de tipo brownfield, com aquisições e ampliações de empresas já existentes. Entre 2007 e 2010, essas operações corresponderam à metade dos investimentos realizados, enquanto as de tipo greenfield somaram 36\%. Em relação à distribuição setorial no mesmo período, ocorreu uma predominância do setor industrial, com 62,5\%, seguido pelo de serviços, com $35,2 \%$. Os investimentos do setor agropecuário totalizaram 2,3\% e foram concentrados em operações no Paraguai e no Uruguai. Por fim, em termos de concentração setorial, os seguintes segmentos se destacavam: alimentos e bebidas, exploração de recursos naturais e energéticos, serviços financeiros e construção civil (Fonseca, 2014).

As grandes empresas brasileiras são atores poderosos e capazes de impactar a política de poder na América do Sul, onde a maioria dos seus interesses está concentrada e onde exercem sua influência em várias esferas, de diversas maneiras e com diferentes resultados. No caso do setor agropecuário, a expansão do agronegócio brasileiro tem provocado reações adversas em alguns vizinhos. Desde 2006, houve um aumento dos investimentos de transnacionais brasileiras 
do setor no Uruguai, que possui uma carne de melhor qualidade e não enfrenta barreiras sanitárias como o Brasil. Em 2013, os embarques uruguaios de carne bovina renderam US $\$ 1,7$ bilhão, enquanto os brasileiros alcançaram a cifra de US\$ 6,7 bilhões. Atualmente, três grupos brasileiros - Marfrig, Minerva e JBS - são responsáveis por $44,6 \%$ dos abates bovinos e $45,9 \%$ das exportações de carnes no país vizinho. Além disso, com quatro frigoríficos no Uruguai, a Marfrig converteu-se na maior empresa privada do país (Olmos, 2014; Tussie, 2013). Como observou Parkinson (2014), o governo uruguaio se preocupa com a excessiva presença do capital brasileiro em sua economia. Para ele, o problema não é a presença, mas a dominância e o elevado poder de mercado das empresas brasileiras.

A situação no Paraguai tem sido um pouco diferente, sobretudo desde a derrubada do presidente Fernando Lugo, em 2012. O atual governo paraguaio tem procurado os empresários brasileiros para realizarem investimentos. Os custos de energia e mão de obra mais baixos têm sido um forte atrativo para as empresas brasileiras instalarem suas fábricas no país vizinho. Em 2014, segundo Soraya Rosar (2015), a CNI coordenou uma missão ao Paraguai que contou com 120 empresários, os quais tiveram um interesse tão grande que foi necessário organizar uma nova missão no mesmo ano. Apesar dos atritos provocados pela presença brasileira no Paraguai e no Uruguai, a autora não acredita que as reações contrárias possam afetar o relacionamento do Brasil com os vizinhos.

Ainda em relação ao Paraguai, Gonzalo Berrón (2015) afirmou em entrevista que o principal incentivo para os investimentos brasileiros no país é o baixo custo da energia. Ele acredita que o investimento produtivo no país vizinho pode contribuir para a integração das cadeias produtivas na região, desde que gere empregos e respeite os direitos trabalhistas. Ademais, a instalação de empresas brasileiras no Paraguai expõe as contradições da integração produtiva, exigindo uma maior reflexão sobre o significado e o alcance de tal integração. 
A concentração de investimentos em operações associadas à exploração de recursos naturais ou grandes projetos de infraestrutura tem gerado problemas para as empresas brasileiras, com reflexos na percepção dos países vizinhos sobre a expansão econômica regional do Brasil. Movimentos sociais de diferentes nacionalidades vêm realizando denúncias e encontros internacionais, coordenando os afetados pela atuação das transnacionais brasileiras, entre as quais se destacam a Vale, a Petrobras e a Odebrecht. A ação agressiva dessas empresas em países de diferentes regiões tem sido divulgada por movimentos da sociedade civil (Fonseca, 2014; Fontes, 2013).

Segundo Gonzalo Berrón (2015), os investimentos brasileiros, sobretudo em obras de infraestrutura, têm um impacto muito alto nas populações dos países receptores. Em muitos casos, os impactos são causados por empresas financiadas pelo BNDES. O autor aponta certa ambiguidade entre as dimensões política e econômica da atuação brasileira, citando o exemplo da Nicarágua. Quando o governo brasileiro se propôs a investir no país centro-americano, a Odebrecht já havia mapeado todas as possibilidades de investimento em infraestrutura. No entendimento de Berrón, esse caso demonstra que os interesses econômicos chegaram antes do governo brasileiro, tornando a relação entre ambos no mínimo suspeita.

Por sua vez, Soraya Rosar (2015) acredita que os conflitos gerados pelas grandes obras de infraestrutura poderiam ser reduzidos caso as empresas brasileiras participassem dos projetos desde o início. Para evitar problemas, ela sugere um acompanhamento mais rigoroso dos projetos por parte do setor privado e dos governos, o que resultaria em uma análise de risco mais completa. Além disso, Rosar afirma que as empresas poderiam abrir escritórios locais antes de iniciar os empreendimentos, a fim de conhecer melhor os países nos quais realizarão seus investimentos.

Nos últimos anos, houve o aumento no número de conflitos envolvendo grandes empresas brasileiras e comunidades indígenas na região. A Petrobras, por exemplo, enfrentou problemas com 
movimentos indígenas de Yasuní, no Equador. Na Bolívia, ocorreu um grave conflito entre povos indígenas e a construtora OAS. O problema surgiu por conta de uma obra que deveria ocorrer na zona amazônica, onde seriam realizados empreendimentos para conectar os dois principais eixos da IIRSA no território boliviano: o eixo Interoceânico Central e o eixo Peru-Brasil-Bolívia. No entanto, a resistência dos povos indígenas bolivianos conseguiu impedir a conclusão de um trecho de $306 \mathrm{~km}$ dessa estrada que atravessaria uma parte do Território Indígena Parque Nacional Isidoro Sécure (TIPNIS). Após esse incidente, o presidente Evo Morales resolveu suspender o contrato com a OAS, que contava com financiamento do BNDES. A politização em torno desses episódios mostrou que a presença de empresas brasileiras nos países vizinhos pode se converter em uma fonte de tensões que afeta diretamente a política regional do Brasil. Ademais, esses conflitos remetem, em alguma medida, às dificuldades para o cumprimento de obrigações contraídas pelos países da região por conta da Convenção 169 da Organização Internacional do Trabalho (OIT), que prevê consulta às populações indígenas em casos de atividade econômica situada em seus territórios de origem (Fonseca, 2014; Hirst, 2013; Klein, 2013). ${ }^{11}$

Como pode ser observado, a atuação das empreiteiras brasileiras tem causado impactos negativos na região, a exemplo do que ocorreu com a OAS na Bolívia. Outra importante construtora, a Odebrecht, tem sido uma destacada participante em diversos projetos financiados pelo BNDES na América do Sul, sendo provavelmente a principal beneficiária dos contratos da IIRSA até o momento. Esta é possivelmente a empresa brasileira mais internacionalizada, atuando em diversos países em diferentes continentes.

${ }^{11} \mathrm{O}$ aumento do conflito coincidiu com a tendência à valorização da natureza no constitucionalismo andino. Em países como a Bolívia e o Equador, os direitos da "mãe natureza" ou Pachamama (em quéchua) passaram a ser tratados constitucionalmente. A constituição equatoriana, por exemplo, define a própria natureza como titular de direitos (Fonseca, 2014). 
Sua atuação, entretanto, não está isenta de conflitos. Em 2008, o presidente Rafael Correa acusou os gestores da empresa de suborno e de terem cometido falhas na construção da usina de San Francisco, expulsando-a do Equador. Correa não só declarou que não compensaria a empresa pelo que já havia construído, mas também se recusou a pagar o empréstimo que tinha sido concedido pelo BNDES (Tussie, 2013). Posteriormente, o embaixador Fernando Simas (2014) informou que o governo equatoriano havia revogado os decretos de expulsão da Odebrecht: a empresa tinha realizado reparos na obra e já estava de volta ao país andino.

As percepções dos demais vizinhos sul-americanos sobre o Brasil oscilam entre negativas e positivas: o país é visto tanto como uma ameaça ou potência subimperialista quanto como um centro de poder com o qual devem se alinhar, pois não estaria disposto a se tornar uma força de policiamento regional. Como afirmou Fernando Simas (2014), há certa ambivalência entre como os vizinhos percebem o Brasil e aquilo que esperam do país. Por um lado, alguns observadores acreditam que o Brasil tem feito pouco para dinamizar a integração sul-americana e atenuar as assimetrias regionais. Por outro, há aqueles que acreditam que o Brasil tem se colocado em uma posição cautelosa para não passar a ideia de que almeja uma expansão hegemônica ou de caráter subimperialista. Portanto, essa aparente ambivalência ou contradição coloca o país em uma situação delicada, pois não preenche as expectativas dos vizinhos em relação à sua atuação nem utiliza suas capacidades da maneira mais eficaz.

Para os críticos à esquerda, o subimperialismo não desapareceu com o fim do padrão industrial diversificado, pois assumiu novas formas sob o padrão exportador de especialização produtiva, seja no neoliberalismo, seja na sua variante neodesenvolvimentista. Segundo Mathias Luce (2013), projetos como a Unasul e a IIRSA colocariam em prática, em nome da integração regional, o papel que o imperialismo reserva ao Brasil na divisão internacional do trabalho. Apesar de não aderir a essa perspectiva, Mônica Hirst (2013) 
alerta para a possibilidade de o Brasil, devido à enorme assimetria em sua relação com a Bolívia, acabar praticando um "imperialismo por default". Para alguns grupos empresariais brasileiros que operam no país andino, a questão da imagem tornou-se uma fonte de preocupação, levando ao temor de uma identificação do Brasil como um país subimperialista.

No entanto, outros autores consideram que a noção de subimperialismo não merece status teórico - nem o Brasil o de país subimperialista -, conquanto se possa, sem rigor, usar essa noção para designar práticas expansionistas de empresas brasileiras apoiadas pelo BNDES, que devem ser rechaçadas. Atualmente, a concepção de imperialismo utilizada concentra-se na esfera econômica, deixando de lado os aspectos políticos do imperialismo analisados por Lênin. Falta, pois, uma análise mais rigorosa sobre a relação política entre os Estados. Além disso, transposições mecânicas e isoladas para a América Latina contemporânea deslocam para contextos históricos completamente diferentes a noção de subimperialismo criada por Ruy Mauro Marini (Berringer, 2013; Sader, 2014; Souza, 2013). Na última década, os Estados sul-americanos criaram fóruns de articulação política que estão nas antípodas da categoria de subimperialismo. Nesse sentido, iniciativas como a Celac e a Unasul vêm garantindo maior autonomia para a região, contrariando, muitas vezes, os interesses hegemônicos dos Estados Unidos.

Nas entrevistas concedidas, os equatorianos Francisco Carrión Mena (2014) e Jorge Acosta Arias (2014) discordam da imagem do Brasil como um país subimperialista. Em relação à expansão das empresas brasileiras, Carrión acredita que é preciso ser mais pragmático e menos idealista. Carrión afirmou que prefere que seja uma empresa brasileira a investir no Equador do que de outra nacionalidade, desde que não pratique atos de corrupção, cumpra a legislação trabalhista e respeite o meio ambiente. Para Arias, o problema não está na participação das grandes construtoras brasileiras, mas nas condições em que elas atuam. Segundo ele, as obras 
não podem ser definidas pelos interesses das empresas contratadas, pois as prioridades estratégicas devem ser definidas pelos Estados. Por sua vez, Gonzalo Berrón (2015) acredita que no auge da expansão dos investimentos brasileiros, entre 2008 e 2012, alguns países temeram um aparente subimperialismo brasileiro. Todavia, as crises internacional e doméstica enfrentadas pelos países da região fizeram com que a percepção de subimperialismo perdesse força.

A maioria dos investimentos brasileiros na América do Sul está ligada ao fortalecimento das políticas desenvolvimentistas de que dependem os recursos externos. Muitos governos progressistas não dispunham de recursos e estrutura para a execução das obras, por isso recorreram à experiência das empresas brasileiras e ao financiamento do BNDES. Dessa forma, projetos como a construção do metrô de Caracas, do porto de Mariel em Cuba, da rodovia na Bolívia e da hidrelétrica no Equador não foram iniciativas do Estado brasileiro, que tampouco recorreu à força militar para garantir a atuação das empresas brasileiras. Na realidade, as mobilizações populares e os problemas ocorridos refletem as contradições inerentes ao desenvolvimento do capitalismo (Berringer, 2013).

Segundo Carlos Fonseca (2014), o processo de expansão das empresas brasileiras na região não é visto de maneira consensual pelos demais países sul-americanos. Nas situações em que os investimentos são mais diversificados, prevalece uma visão mais otimista dos países receptores, devido aos impactos gerados na criação de empregos, nos ganhos de produtividade e no aumento da capacidade exportadora. No entanto, o diagnóstico torna-se diferente quando a presença empresarial está concentrada nos setores intensivos em recursos naturais ou ainda na construção civil. Nesses casos, a presença das empresas, somada ao apoio financeiro público estatal, pode apresentar-se como um complicador adicional, levando o governo brasileiro para o centro das crises e dos conflitos.

Um balanço provisório sobre a presença das transnacionais brasileiras na região permite identificar aspectos negativos e posi- 
tivos. De acordo com Nikolai Bukharin (1984), todo capitalismo nacional tende a estender-se para além das suas fronteiras territoriais. Com o Brasil não foi diferente. Apesar de o país não exportar os seus instrumentos de coerção, como fizeram os países europeus analisados pelos teóricos do imperialismo, a atuação das suas empresas tem causado impactos negativos nas populações vizinhas. De fato, o Brasil tem um setor privado dinâmico que pode contribuir para o desenvolvimento regional. No entanto, os Estados da região devem ser responsáveis pelo planejamento dos projetos estratégicos, que não podem ser delegados à iniciativa privada. Nesse sentido, o Brasil deveria assumir mais responsabilidades e refletir sobre as consequências da expansão econômica de suas empresas para o seu projeto de regionalismo, tomando eventuais medidas para minorar os impactos negativos e maximizar os resultados positivos.

Em síntese, o capitalismo de Estado contribuiu decisivamente para transformar o Brasil no país mais industrializado da América Latina em poucas décadas. A estratégia desenvolvimentista foi responsável por elevadas taxas de crescimento e pela criação de empresas estatais e privadas dinâmicas. Assim, deve-se destacar o papel desempenhado pelo BNDES em diferentes momentos na trajetória do desenvolvimento brasileiro. Nas últimas décadas, ocorreu uma intensificação da internacionalização das grandes empresas dos países em desenvolvimento, que alcançou a região, com o surgimento das chamadas translatinas. No entanto, a nova fase da expansão do capitalismo brasileiro coincidiu com a ascensão dos governos progressistas, e isso tendeu a gerar conflitos entre as lógicas diplomática e empresarial. Apesar de atuarem em diferentes países e regiões, observa-se uma concentração das empresas brasileiras na América do Sul, a qual tem gerado impactos negativos em países vizinhos, sobretudo quando envolve megaprojetos. Em certos casos, isso gera uma percepção de que o Brasil seria um país subimperialista. As análises nesse sentido, todavia, entram em contradição com projetos contra-hegemônicos, como a Unasul. 


\subsection{A integração da infraestrutura regional: da IIRSA ao Cosiplan}

Nesta seção, será analisada a importância da integração física para a consolidação de um regionalismo autônomo. Historicamente, a região esteve vinculada aos mercados externos, o que provocou um déficit estrutural de interconexões ligando internamente os países. Nos anos 1990, a retomada do conceito de América do Sul ocorreu juntamente com a proposta da IIRSA. Assim, o projeto de integração física precedeu a articulação política. Desde a ascensão dos governos progressistas, tem havido uma tentativa de mudar o caráter do projeto integracionista, fortemente marcado pelo regionalismo aberto e pelo ideário liberal. Nesse sentido, os países da Unasul criaram o Cosiplan com o objetivo de dotar a integração física de caráter geopolítico. Apesar dos esforços nessa direção, ainda há obstáculos que precisam ser superados para que o processo de integração contribua efetivamente para a superação das assimetrias e o processo de desenvolvimento regional.

Um conjunto de fatores - históricos, geográficos, econômicos e políticos - contribuiu para que houvesse uma dispersão no arranjo das principais áreas de concentração populacional e econômica da América do Sul. Ao longo do tempo, essas áreas se concentraram na faixa litorânea e estiveram voltadas para o comércio exterior, inexistindo ou existindo apenas precariamente conexões viárias entre elas. A história da ocupação e da colonização sul-americana privilegiou o estabelecimento de pontos de conexão ao longo do litoral, portanto toda a infraestrutura viária e de comunicações foi articulada a partir dos portos. Ao exportar as mesmas matérias-primas e importar produtos manufaturados de fora da região, nenhum vínculo econômico se formou entre os países sul-americanos. Assim, a forma tradicional de desenvolvimento, nos moldes da divisão internacional do trabalho surgida na época do Pacto Colonial e ampliada na primeira fase 
da Revolução Industrial, contribuiu para consolidar a fragmentação no subcontinente (Furtado, 2007; Padula, 2011b).

Do ponto de vista geográfico, a América do Sul é um continente fracionado, que pode ser caracterizado como um vasto arquipélago com escassas conexões inter-regionais. Enquanto as regiões costeiras possuem alta densidade populacional, o miolo do território representa um grande vazio. Nas baixas latitudes, a população, para evitar as temperaturas mais quentes, sobretudo nos países banhados pelo Pacífico, priorizou as zonas andinas. Em contrapartida, nos países voltados para o Atlântico, houve uma concentração demográfica no litoral. Pela oposição das duas vertentes oceânicas ou pela existência das zonas excludentes, ocorreu o surgimento de espaços geopolíticos neutros que, por sua posição no hinterland, predispuseram os países sul-americanos a uma dissociação econômica. Dessa forma, o potencial de comércio entre as principais áreas econômicas da região, especialmente entre os dois oceanos, não foi devidamente explorado. Por sua vez, o centro da região, área dotada de importantes recursos e ecossistemas, nunca foi estrategicamente ocupado e interligado ao continente; a escassez de integração física pode ser considerada o principal obstáculo a uma efetiva integração sul-americana. Nesse sentido, muitos analistas acreditam que o caminho para a conformação de um bloco de nações na América do Sul passa necessariamente pela interconexão dos espaços físicos desses países (Costa, 2013; Padula, 2011b; Severo, 2011).

No plano do Estado-nação, uma maior capacidade de mobilidade, aproveitamento e ocupação dos espaços pode gerar o aumento da coesão interna e a projeção geopolítica, possibilitando explorar seu potencial continental ou marítimo. Isso ocorreu, por exemplo, nos Estados Unidos ainda no século XIX, quando o país logrou ligar o Atlântico ao Pacífico e projetar o seu poder além das suas fronteiras (Amorim, 2009; Padula, 2011a). A falta de infraestrutura constitui um obstáculo para a implementação de uma política eficaz de desenvolvimento. A infraestrutura e seus serviços conexos, por- 
tanto, atuam como veículos para a coesão territorial, econômica e social, pois, além de melhorar a conectividade, reduzir os custos de transporte e facilitar a mobilidade, também facilitam o desenvolvimento social das diversas regiões, tornando-as acessíveis do exterior e permitindo que os habitantes se conectem com seu entorno e os serviços fundamentais para a produção e o melhoramento das condições de vida das pessoas. Com isso, observa-se uma relação positiva entre infraestrutura e desenvolvimento socioeconômico, visto que aquela é fundamental para o crescimento econômico e o desenvolvimento territorial equilibrado, e sua ampliação contribui para reduzir as desigualdades regionais e locais (CEPAL, 2012). ${ }^{12}$

No caso da América do Sul, o aprofundamento da integração passa pelo fortalecimento da interconexão física regional. Da mesma forma que ocorreu com outros blocos econômicos, como a UE, a união da infraestrutura regional é condição necessária para a integração produtiva, comercial, política e social dos países sul-americanos. De fato, a integração física pode contribuir para a superação das assimetrias territoriais. Nesse sentido, a provisão de infraestrutura em territórios historicamente isolados pode ajudar na distribuição territorial dos investimentos e na interiorização do desenvolvimento, gerando um processo mais harmonioso de integração regional. Francisco Carrión Mena (2014) foi taxativo ao afirmar que a expansão da infraestrutura física é um dos mecanismos mais importantes para a consolidação do regionalismo. Para o ex-chan-

\footnotetext{
${ }^{12}$ A infraestrutura física demanda ações planejadas e integradas. Entre suas características mais importantes, destacam-se: 1) seus serviços básicos que geram amplas externalidades e viabilizam e pré-condicionam o desenvolvimento e a interligação de uma grande variedade de atividades econômicas e de regiões; 2) exigência de elevados investimentos, com indivisibilidade técnica, que produzem efeitos multiplicadores e de encadeamento e demanda por toda a economia - necessitando de serviços de engenharia qualificados e trabalho não qualificado em sua construção, criando empregos (diretos e indiretos) e renda; 3) seus investimentos que, além de induzir mais destes, modificam o meio ambiente e apresentam longo período de maturação. Desde o século XIX, os investimentos no setor têm mostrado sua importância para o desenvolvimento dos países (Padula, 2011a).
} 
celer, a integração física contribui para romper com os esquemas tradicionais de integração e é um dos pontos fortes da Unasul.

Apesar de sua importância estratégica, a infraestrutura da América do Sul tem enfrentado sérios problemas desde a eclosão da crise da dívida dos anos 1980 . Um resultado claro da defasagem acumulada é o crescimento da chamada brecha de infraestrutura, ou seja, as diferenças entre sua oferta e demanda. Segundo a CEPAL (2012), a região investe cerca de 2,3\% de seu PIB anual em infraestrutura (algo em torno de US\$ 53,5 bilhões em valores de 2000), quando deveria investir entre $5,7 \%$ e $8,1 \%$ do PIB regional (isto é, entre US\$ 128 e US\$ 180 bilhões em valores de 2000) para dar uma resposta favorável à escassez de infraestrutura - incluindo a expansão da capacidade e sua manutenção. As carências provocadas pela brecha de infraestrutura se traduzem em elevados custos logísticos e de transporte, os quais, atualmente, têm um peso maior do que as tradicionais barreiras comerciais. Diferentes estudos estimam que os custos logísticos nos países sul-americanos se situam entre 16\% e $25 \%$, contrastando com a média de $9 \%$ registrada nos países da OCDE. Tal situação tem um impacto negativo direto não só sobre a produtividade dos agentes econômicos e a competitividade das empresas, mas também no desenvolvimento e na articulação dos territórios e mercados, tanto no âmbito nacional como no regional. Esse conjunto de fatores limita, portanto, o potencial de desenvolvimento socioeconômico dos países da Unasul (CEPAL, 2012).

Além da brecha de infraestrutura, a CEPAL (2012) identificou que o enfraquecimento do papel do Estado, principalmente na década de 1990, provocou a diminuição do uso de instrumentos e ferramentas de planejamento. Estudos realizados na área de infraestrutura e transporte indicam que há um divórcio entre as políticas de desenho e provisão de infraestrutura e aquelas de operação e promoção do transporte. Tal dissociação decorre do fato de que, na maioria dos casos, a infraestrutura é planejada em uma instituição e implementada por outra, e a regulação dos serviços costuma ser 
realizada por um terceiro que sequer participou de seu desenho. A falta de integração entre a formulação e a implementação dessas políticas setoriais gera uma operação mais onerosa, insegura e carente de efeitos sinérgicos positivos no desenvolvimento local, nacional e regional. Além disso, ao enfatizar estradas no lugar de sistemas logísticos ferroviários e hidroviários, os países sul-americanos optaram pelo modal mais custoso e ambientalmente menos favorável para seu sistema de transportes, o rodoviário, que concentra mais de $50 \%$ do transporte de carga entre os países da América do Sul, apesar de a região apresentar uma geografia natural favorável ao sistema aquaviário - cabotagem, hidroviário ou marítimo. Assim, a região tem o desafio de construir uma política setorial alternativa mais eficiente, menos dispendiosa de energia e ambientalmente mais favorável, a fim de construir um espaço sul-americano capaz de projetar a região e impulsionar o desenvolvimento de seus países (CEPAL, 2012; Padula, 2011a e 2011b).

Desde os anos 1970, a ideologia dominante no âmbito da geografia (e demais campos das ciências sociais) disseminou a ideia de que os fluxos econômicos se sobreporiam cada vez mais ao poder dos Estados e aos seus limites político-territoriais definidos, gerando uma nova lógica territorial sobre a "velha" geopolítica dos Estados nacionais. De acordo com esse pensamento, a construção da infraestrutura deveria apoiar os fluxos existentes ou potenciais, o que nos países periféricos favoreceria a constituição ou reforço de corredores de exportação/importação. Tal visão da infraestrutura reflete determinada concepção de integração regional, que enfatiza os acordos de livre comércio e a conexão com o mercado global, sobrepondo os corredores de exportação aos de integração, "para dentro". A partir disso, os objetivos geopolíticos deveriam ser substituídos por uma perspectiva regional geoeconômica, centrada na facilitação dos fluxos e na busca de vantagens comparativas estáticas (Padula, 2011a, 2011b). 
A concepção mercantil do espaço geográfico, defendida pelo grande capital, contribui para compartimentalizar territórios e disseminar infraestruturas necessárias à desejada fluidez nos lugares que considera necessários para a sua atividade. Há, contudo, sempre uma seletividade nessa difusão, separando os espaços de pressa daqueles destinados à morosidade. De acordo com essa lógica, cada empresa utiliza o território em função dos seus fins próprios e exclusivamente em função desses fins. Nesse sentido, o geógrafo Milton Santos (2007, p. 107) tem razão quando afirma que "nessas condições, a tendência é a prevalência dos interesses corporativos sobre os interesses públicos, quanto à evolução do território, da economia e das sociedades locais".

Com a crescente integração dos mercados regionais, as redes logísticas passaram a ter um papel geopolítico fundamental. $\mathrm{Na}$ ausência de projetos nacionais de longo prazo, a participação das corporações e das instituições multilaterais tornou-se cada vez mais determinante para os destinos das populações sul-americanas. Entre os anos 1990 e o início da década seguinte, os debates sobre integração regional foram influenciados pelas propostas do regionalismo aberto ${ }^{13} \mathrm{da}$ CEPAL e do novo regionalismo do BID, que incluíam, entre seus objetivos, temas como infraestrutura. Essas abordagens serviram de sustentação teórica para a formulação do modelo de integração física e regional que resultaram na IIRSA. Dentro dessa visão, o papel centralizador do Estado deveria ceder lugar ao planejamento descentralizado e flexível dos mercados e das instituições financeiras multilaterais. O processo de integração regional e a construção da infraestrutura deveriam ser funcionais ao processo de liberalização econômica internacional. Além disso, os projetos deveriam atrair investimentos externos para a criação e a expansão

${ }^{13}$ Nos anos 1990, a CEPAL publicou documento no qual defendia a ideia de regionalismo aberto, cujo objetivo era conciliar a integração regional com os processos de liberalização comercial. 
de corredores de exportação de produtos regionais de baixo valor agregado (Padula, 2011a, 2011b; Severo, 2011).

A IIRSA surgiu durante a I Reunião de Presidentes da América do Sul, que ocorreu em Brasília entre 31 de agosto e $1 .^{\circ}$ de setembro de 2000. Desde sua criação, a IIRSA adota uma visão geoeconômica da articulação do território e tem como principal objetivo promover a integração física nas áreas de transporte, comunicações e energia. A iniciativa foi influenciada pela hegemonia ideológica dos governos neoliberais que estavam no poder na época, dentro da lógica do regionalismo aberto e com o propósito de contribuir para a formação de uma área de livre comércio regional. Nesse sentido, a IIRSA seria a coluna do bloco de livre comércio sul-americano, formando, com o Plano Puebla-Panamá outra iniciativa ligando a América Central à América do Norte -, a coluna central da integração física da Alca, projeto que era apoiado pelo Comunicado de Brasília (CEPAL, 2012; IIRSA, 2000; Martins, 2011; Padula, 2011b; Severo, 2011). ${ }^{14}$

A IIRSA foi criada como um projeto regional capitaneado por instituições financeiras multilaterais com forte presença na região, como o BID, a CAF e o Fundo Financeiro para o Desenvolvimento da Bacia do Prata (Fonplata). No encontro de Brasília, os então presidentes do BID e da CAF, Enrique Iglesias e Enrique Garcia, respectivamente, tiveram presença marcante. As três instituições tiveram papel ativo na formação e, posteriormente, na coordenação e no gerenciamento da IIRSA. Apesar das mudanças

\footnotetext{
${ }^{14}$ No ponto 33 do Comunicado de Brasília, os presidentes sul-americanos reafirmavam que o processo de formação de um espaço econômico ampliado na região obedecia aos princípios do "regionalismo aberto" e deveria reforçar a posição dos países da América do Sul em negociações importantes, como a que previa a criação de uma área de livre comércio das Américas. No ponto 34, os mandatários sul-americanos reafirmavam seu apoio ao processo de aprofundamento e expansão da integração econômica no hemisfério. Ademais, mostravam-se satisfeitos com a V Reunião Ministerial da Alca, realizada em Toronto em 1999, reafirmando seu compromisso com a construção progressiva de uma área de livre comércio nas Américas, cujas negociações deveriam estar concluídas até 2005 (IIRSA, 2000).
} 
surgidas após a criação da Unasul, esses três organismos continuam integrando o Comitê de Coordenação Técnica (CCT) da IIRSA, que era o órgão responsável por selecionar e hierarquizar os projetos apresentados pelos governos dos países sul-americanos. Além disso, o CCT tinha como objetivo promover a participação da iniciativa privada e captar recursos para a execução dos projetos, que eram hierarquizados com base em critérios econômico-financeiros (Costa, 2010; Padula, 2011b; Severo, 2011).

Em seus primeiros anos, a IIRSA careceu de marco intergovernamental, acordo ou tratado. Segundo sua estrutura institucional, os trabalhos técnicos e o Plano de Ação da iniciativa deviam ser guiados pelas diretrizes e prioridades estabelecidas pelos governos, a partir de um conselho de ministros de planejamento e infraestrutura, cujos membros formavam o Comitê de Direção Executiva (CDE). Nessa estrutura, o CDE era a instância máxima responsável pelas decisões políticas e deveria se reunir uma vez por ano. Os Grupos Técnicos Executivos (GTE) tinham como objetivo analisar e compatibilizar os marcos regulatórios e normativos, além de avaliar os projetos de forma integrada. A coordenação dos trabalhos e dos grupos técnicos cabia às agências multilaterais - BID, CAF e Fonplata - que integravam o CCT, instituído como secretaria executiva do CDE. Por fim, as Coordenações Nacionais de cada um dos doze países deveriam coordenar a participação de cada integrante da IIRSA, articulando a participação de governos e setores da sociedade, sobretudo daqueles ligados ao empresariado (Costa, 2010; Padula, 2011b).

A liderança e a influência do Brasil foram decisivas na estruturação e nos rumos da IIRSA. No início, a proposta foi tratada pelo governo brasileiro com base em uma visão estritamente técnica e não político-estratégica. A condução da IIRSA ficou a cargo de uma Comissão Interministerial criada em 2001, formada pelo Ministério do Planejamento, Orçamento e Gestão (MPOG) - que exercia sua coordenação - e pelos Ministérios dos Transportes, das Minas e Energia e das Comunicações. O Itamaraty não foi incluído inicial- 
mente na comissão, cenário que mudaria apenas no governo Lula. Além disso, a IIRSA foi concebida como uma ferramenta-chave do Brasil para pavimentar suas políticas para a América do Sul, incluindo a expansão das suas empresas na região. A iniciativa tem sido alvo frequente de críticas de movimentos da sociedade civil, que sofrem com o impacto das obras. Esses grupos têm denunciado que o desmembramento dos projetos em várias partes é uma maneira de burlar leis ambientais, visto que dificulta a avaliação dos impactos socioambientais dos projetos em seu conjunto (Klein, 2013; Padula, 2011 b; Tussie, 2013). ${ }^{15}$

Do ponto de vista físico e espacial, a IIRSA previa a aplicação do conceito de Eixos de Integração e Desenvolvimento (EID), proposto por Eliezer Batista, que havia sido Ministro das Minas e Energias do governo João Goulart (1961-64), presidente da Vale (1979-86) e Secretário de Assuntos Estratégicos do governo Collor (1990-92). Os EIDs já tinham sido utilizados como modelo para a concepção de dois Planos Plurianuais (PPA) do Brasil: o PPA de 1996-99 ("Brasil em ação") e o PPA de 2000-03 ("Avança Brasil”). Apesar de representar uma inovação no planejamento da infraestrutura, os EIDs eram influenciados pelo regionalismo aberto e pela priorização dos corredores de exportação, sendo, portanto, totalmente atrelados à lógica neoliberal de conexão entre logística e inserção nos fluxos de comércio internacional. Dentro dessa ótica, o planejamento da infraestrutura deveria ser realizado sob uma perspectiva geoeconômica, buscando a eficiência e outras vantagens a serem obtidas por meio de uma visão da região como uma única unidade econômica. Assim, a IIRSA recepcionou uma proposta metodológica nacional que tendia a reforçar, no âmbito regional, uma inserção internacional baseada nas exportações de

${ }^{15}$ Segundo Magno Klein (2013), os projetos integrantes da IIRSA afetavam comunidades indígenas, populações tradicionais e ribeirinhos em 137 Unidades de Conservação, o que correspondia à metade de toda a área demarcada para a preservação no Brasil. 
bens primários e na cristalização da divisão regional do trabalho (Albuquerque, 2013; Costa, 2010; Costa e Gonzalez, 2014; Padula, 2011 b; Severo, 2011).

O Plano de Ação da IIRSA foi elaborado pelo BID e pela CAF e continha sugestóes e propostas para um horizonte temporal de dez anos. Esse plano foi bem recebido pelos presidentes que participaram do encontro de Brasília e dava especial atenção às dificuldades geográficas dos países da região para terem acesso aos mercados internacionais. Como primeiro pilar, o plano previa seis Processos Setoriais de Integração (PSI), que objetivavam melhorar as deficiências de setores que inibiam a integração. ${ }^{16} \mathrm{O}$ seu segundo pilar consistia em dez Eixos de Integração e Desenvolvimento - na realidade, os EIDs continuam presentes e podem ser observados na figura 5. A articulação da América do Sul para fora está subentendida no desenho dos EIDs, que são voltados para a costa e enfatizam as ligações bioceânicas e leste-oeste (Costa e Gonzalez, 2014; Martins, 2011; Padula, 2011b).

${ }^{16}$ Os seis processos que deram origem aos EIDs são: 1) sistemas operativos de transporte multimodal; 2) sistemas operativos de transporte aéreo; 3 ) facilitação de passos de fronteira; 4) tecnologia da informação e comunicações; 5) instrumentos para o financiamento de projetos de integração; 6) integração energética (Costa e Gonzalez, 2014). 
Figura 5 - IIRSA: Eixos de Integração e Desenvolvimento

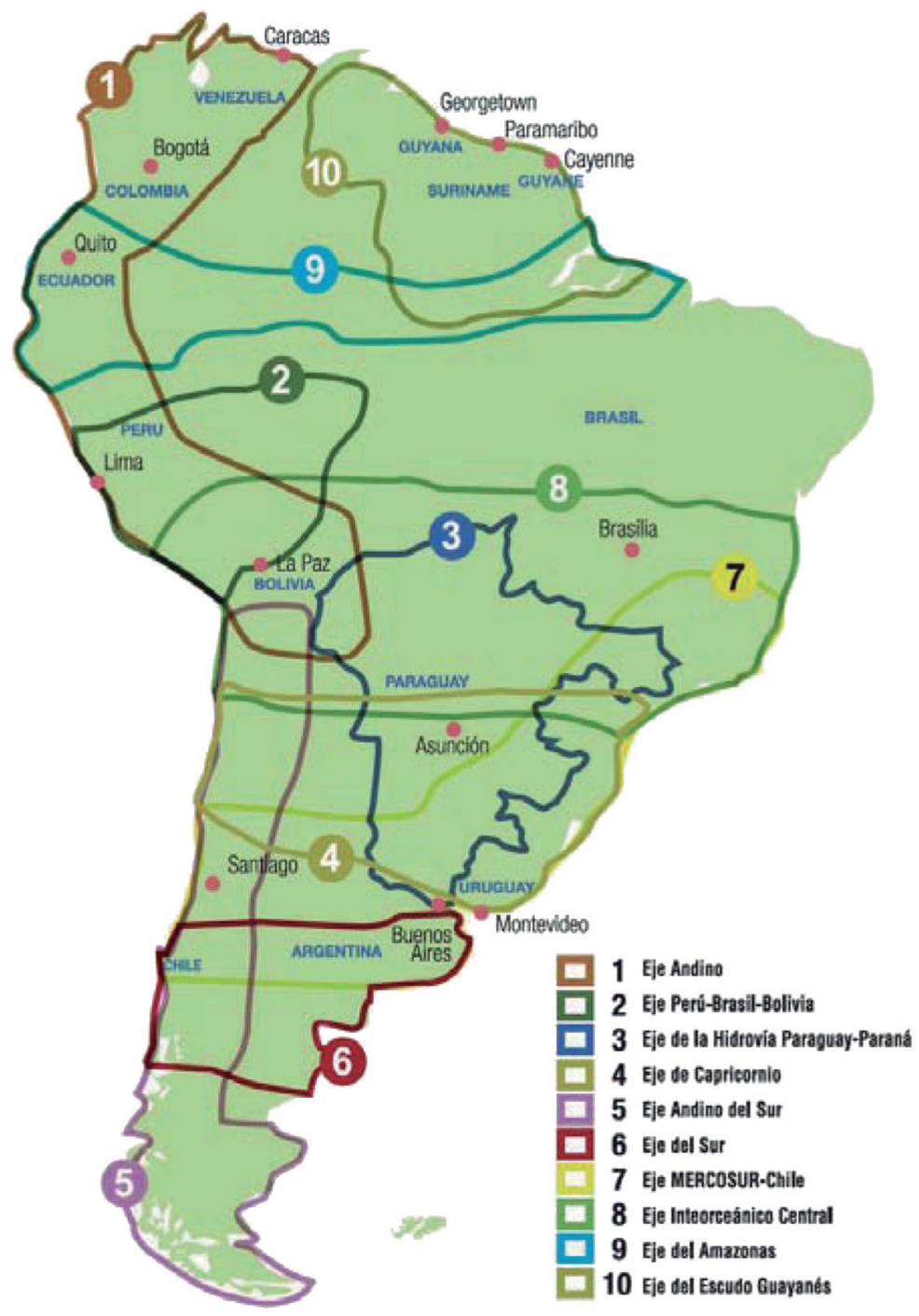

Fonte : IIRSA, 2015. 
Entre 2000 e 2004, a IIRSA passou por uma primeira etapa de planejamento, quando foram elaborados estudos sobre o potencial de integração de cada EID, além de diagnósticos sobre impactos normativos e regulatórios da integração física regional. Nesse período, iniciaram-se estudos para ampliar a participação do setor privado na iniciativa, e foram realizados trabalhos para formar uma carteira de operações que somavam 335 projetos, totalizando investimentos da ordem de US\$ 37 bilhões em 2004. No final desse ano, durante a III Reunião de Presidentes da América do Sul, em Cusco, foi anunciada a Agenda de Implementação Consensuada (AIC) 2005-10, documento que refletia o consenso dos doze países da região em torno de uma nova estratégia de execução da IIRSA. Com investimentos estimados em US\$ 14 bilhões, a AIC tinha por objetivo financiar e executar no curto prazo um conjunto de 31 projetos prioritários de alto impacto para a integração física da região. No encontro do Peru, a visão liberal do projeto integracionista foi abandonada com a criação da CSN, mas a IIRSA manteve a mesma linha de regionalismo aberto, ainda que alguns projetos da carteira tenham sido ajustados (CEPAL, 2012; Costa e Gonzalez, 2014; Padula, 2011b).

O valor total da AIC 2005-10 chegou a aproximadamente US 7 bilhões, ou 0,3\% do PIB regional, e todos os países foram contemplados com pelo menos um projeto. Segundo a distribuição geográfica dos 31 projetos, 16 eram nacionais, 12 binacionais, um trinacional e somente dois regionais. Em relação à divisão por setor, 28 projetos foram concentrados no setor de transporte, dois na área de comunicações e um em energia. Na divisão por modais, 24 projetos eram rodoviários, dois hidroviários, dois ferroviários e um dutoviário, sendo o último identificado como um projeto na área de energia. Nesse sentido, a AIC não promoveu mudanças na matriz de transportes, pois sua carteira contribuiu para a manutenção e reprodução do padrão existente (Costa e Gonzalez, 2014; Padula, 2011b; Severo, 2011). 
Durante a primeira década da IIRSA, a carteira passou de 335 projetos, em 2004, para 524, em 2010, representando investimentos da ordem de US\$ 96 bilhões. De acordo com a CEPAL (2012), entretanto, apenas 53 projetos ou 10\% do total haviam sido concluídos nesse período; dos 31 projetos da AIC, apenas três encontravam-se finalizados no final de 2010. Esses números indicavam que, após dez anos do lançamento da IIRSA, muito pouco havia avançado em termos de resolução efetiva dos gargalos logísticos da região. Dos projetos concluídos, apenas um - uma operação de pavimentação interligando a Amazônia peruana à região andina, no eixo Peru-Brasil-Bolívia - podia ser considerado como estruturante do ponto de vista da integração física regional. Os outros dois projetos, uma ponte sobre o rio Acre e outra sobre o rio Takutu, foram operações pouco complexas do ponto de vista técnico e financeiro, ambos financiados integralmente com recursos orçamentários do governo brasileiro (CEPAL, 2012; Costa e Gonzalez, 2014).

A IIRSA surgiu em uma conjuntura de mudança parcial da política externa do governo Fernando Henrique, trazendo consigo uma linha neoliberal e escassa institucionalização. Com a ascensão de Lula, a política externa de seu governo procurou retomar o controle público sobre o projeto de integração física, atuando para que a IIRSA fosse incorporada à Unasul. Para isso, o Itamaraty assumiu mais responsabilidades em relação à iniciativa, até então restrita à alçada do MPOG. Como lembrou o ministro Parkinson (2014), o Itamaraty pode complementar a análise do MPOG, agregando elementos políticos à dimensão técnica dos projetos de infraestrutura. No âmbito regional, a ascensão dos governos progressistas e a criação da CSN levaram ao surgimento de um ambiente favorável para a plena incorporação da IIRSA à Unasul, o que ocorreria com a criação do Cosiplan.

Em agosto de 2009, na III Reunião de Chefes de Estado da Unasul, realizada em Quito, foi criado o Cosiplan, um órgão de 
coordenação e articulação de programas e projetos de integração da infraestrutura regional dos países. $\mathrm{O}$ novo conselho é integrado pelos ministros das áreas de infraestrutura, planejamento ou obras públicas dos doze Estados-membros e seu objetivo é obter apoio político para as atividades e os projetos que gerem desenvolvimento econômico e social sustentável para a América do Sul. Apesar de a incorporação da IIRSA à Unasul favorecer maior participação dos governos na integração física regional, isso não garante uma mudança na visão dominante sobre o tema. Assim, o desafio do Cosiplan é identificar gargalos de financiamento e produzir sinergias para executar projetos que contribuam para aumentar a integração física e o desenvolvimento para dentro da região, em vez de pautar-se apenas pelas condicionalidades e diretivas oriundas das grandes instituições multilaterais de crédito (CEPAL, 2012; Costa e Gonzalez, 2014; Padula, 2011b; Simões, 2010).

Em junho de 2010, realizou-se, em Quito, a primeira reunião do Cosiplan, tendo como objetivos principais aprovar o Regulamento, o Estatuto e as linhas de ação do conselho. Nesses documentos, definiu-se pela incorporação da IIRSA à Unasul como um órgão técnico do Cosiplan, a fim de aproveitar a experiência técnica e a competência metodológica daquele fórum. Com o intuito de dar continuidade aos trabalhos realizados pela IIRSA, o Cosiplan assumiu o lugar do órgão executivo da iniciativa (CDE) e passou a contar com o apoio do Comitê de Coordenadores Nacionais e de um Foro Técnico, formado pelas instituições financeiras do CCT da IIRSA - BID, CAF e Fonplata. A expectativa era que o Cosiplan conferisse um tratamento adequado a todas as questões, acrescentando a vantagem de ser um foro político de alto nível. Com essas mudanças, a IIRSA passou a receber diretrizes políticas dos países da Unasul, e não mais das agências financeiras do CCT (Albuquerque, 2013; Padula, 2011b). A figura 6 apresenta o atual organograma do Cosiplan. 
Figura 6 - Cosiplan: estrutura organizacional

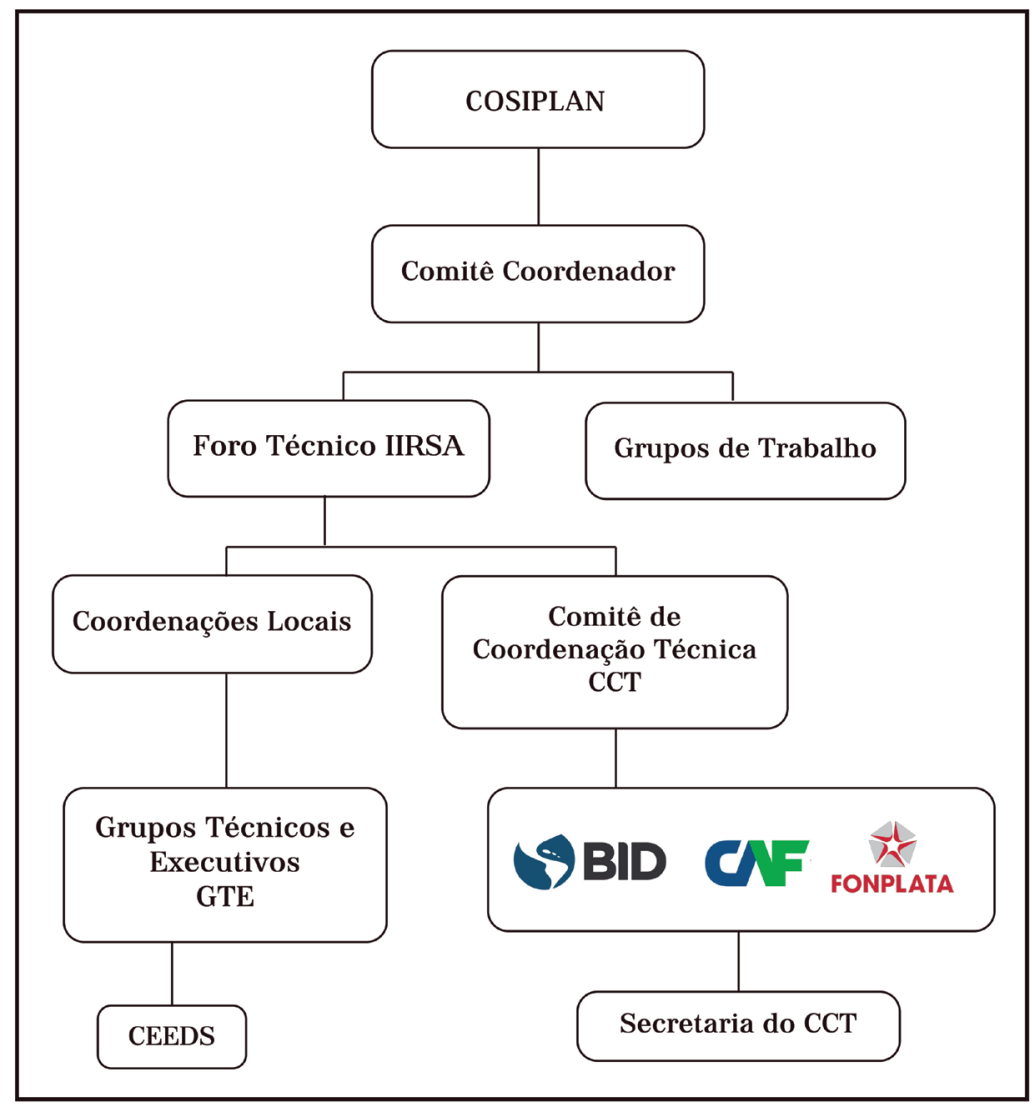

Fonte : IIRSA, 2015.

Com o fim da gestão BID-CAF à frente da IIRSA em 2010, houve uma abertura para que os Tesouros Nacionais e o BNDES se envolvessem mais no financiamento dos projetos de integração, fato este que, na realidade, começou no início do governo Lula. Em 2003, foi realizado um seminário internacional envolvendo o BNDES e a CAF que resultou em um acordo de atuação conjunta na América do Sul, visando ao fortalecimento da integração 
regional. Em 2007, o Brasil reforçou sua participação na CAF, passando de sócio acionista série $\mathrm{C}$ para sócio acionista série $\mathrm{A}$ - vale ressaltar que a CAF é a instituição mais importante em matéria de financiamento à infraestrutura regional. Na mesma época, ocorreu uma reestruturação do Fonplata. No entanto, deve-se destacar que, por questões estatutárias, os financiamentos do BNDES estão obrigatoriamente associados à prestação de serviços técnicos e de engenharia de empresas brasileiras, assim como à exportação de bens produzidos no Brasil. Houve, portanto, uma convergência entre as disponibilidades orçamentárias do BNDES e a demanda regional por investimentos em infraestrutura que possibilitou às transnacionais brasileiras atuarem nesses territórios (Além e Cavalcanti, 2005; Berringer, 2013; Carvalho e Sennes, 2009; Severo, 2011).

Ainda em relação ao financiamento da infraestrutura, Diego Cardona (2014) afirmou em entrevista que houve um declínio do papel do BID e um incremento da atuação do BNDES desde a criação do Cosiplan. Enquanto o BNDES tem atuado principalmente em projetos envolvendo o Brasil, a CAF continua sendo a principal agência financiadora dos projetos relacionados aos demais países. Todavia, João Carlos Parkinson (2014) afirmou também em entrevista que a participação do Banco brasileiro deverá diminuir com as medidas anunciadas pelo governo de cortar os repasses do Tesouro ao BNDES. Apesar da sua importância, a atuação do Banco é insuficiente para resolver o problema da integração da infraestrutura regional. Segundo Parkinson, a superação da brecha de infraestrutura e os recursos necessários para os investimentos na área só virão com a criação de um banco de atuação regional, como o Banco do Sul.

Durante o processo de institucionalização do Cosiplan, foram aprovados, em novembro de 2011, em Brasília, o Plano de Ação Estratégica 2012-22 (PAE) e a Agenda Prioritária de Projetos de Integração (API). Em relação ao PAE, trata-se de um conjunto de objetivos e ações que resumem o encaminhamento estratégico do Cosiplan, o qual 
determina que o conceito de eixo de integração e desenvolvimento seja ampliado de maneira a privilegiar o desenvolvimento sustentável e a redução das assimetrias existentes na região. Dentro desse âmbito, foi aprovada a metodologia para a formulação de Programas Territoriais de Integração (PTI), os quais deverão potencializar o impacto da infraestrutura no desenvolvimento dos territórios envolvidos nos projetos, levando em consideração os aspectos econômicos, sociais e ambientais. Além disso, procurou-se aperfeiçoar a metodologia de avaliação ambiental e social com enfoque estratégico, conhecida como EASE, que tem o propósito de fornecer um marco conceitual e de orientações práticas para identificar, caracterizar e avaliar as consequências sociais e ambientais, os riscos e as oportunidades associadas ao desenvolvimento dos projetos de infraestrutura (Albuquerque, 2013; Costa e Gonzalez, 2014; Unasul, 2014). Segundo Parkinson (2014), a metodologia EASE foi testada pela primeira vez com sucesso no projeto de transporte multimodal Lagoa Mirim-Patos, no Rio Grande do Sul. O ministro afirmou também que as novas metodologias e preocupaçóes - ambientais, sociais, territoriais - confirmam as mudanças que ocorreram com a absorção da IIRSA pelo Cosiplan.

$\mathrm{Na}$ XXV reunião de coordenadores nacionais do Cosiplan, realizada em Montevidéu, em dezembro de 2014, o relatório de atividades trouxe alguns dados atualizados sobre a carteira de projetos. Na época, a carteira contava com 583 projetos, divididos em 48 grupos de projetos e 9 EIDs, com um valor aproximado de US\$ 162 bilhões. O setor de transporte concentrava a maioria dos projetos, com $89 \%$ do total. Já os setores de energia e comunicações detinham 9,3\% e 1,6\%, respectivamente, do conjunto da carteira Cosiplan (IIRSA, 2014; Unasul, 2014).

Em relação à API, deve-se destacar que essa carteira é resultante de um esforço de cooperação e diálogo consensual entre os Estados-membros da Unasul, com o intuito de melhorar o processo de planejamento territorial e identificar os projetos mais relevantes. No relatório de atividades de 2014, a API contava com cem pro- 
jetos individuais, organizados em 31 projetos estruturados, com um valor global de aproximadamente de US $\$ 21$ bilhões. O baixo índice de conclusão dos projetos pode ser verificado no gráfico 6 , que os apresenta por etapa do ciclo de vida. Apesar de um pouco mais equilibrada do que a carteira AIC 2005-10, os projetos ainda reproduzem o modelo de integração física baseado no transporte rodoviário. Este, embora apresente custos de implementação mais baixos, caracteriza-se como economicamente pouco eficiente, tendo em vista a magnitude do território e os custos ambientais envolvidos (Costa e Gonzalez, 2014; IIRSA, 2014; Unasul, 2014).

Gráfico 6 - Cosiplan: projetos por etapa do ciclo de vida
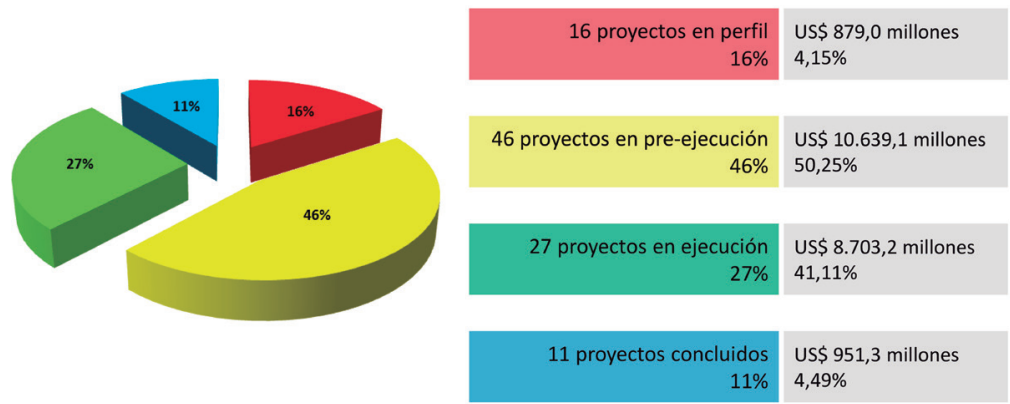

Fonte: IIRSA, 2014.

Nas entrevistas, procurou-se verificar se houve mudanças no processo de integração física regional com a criação do Cosiplan e a incorporação da IIRSA à Unasul. Para Fernando Simas (2014), não houve uma descontinuidade entre a IIRSA e o Cosiplan, nem uma inflexão radical entre os governos Fernando Henrique e Lula. A principal mudança foi no sentido de mobilizar mais recursos para o financiamento dos projetos de infraestrutura. Por sua vez, Jorge Acosta Arias (2014) afirmou que a concepção da IIRSA não sofreu grandes alterações após sua integração ao Cosiplan. Além da per- 
sistente falta de recursos, Arias criticou a ausência dos ministros de planejamento nas reuniões do Cosiplan. Para mudar esse quadro, o Equador e a Venezuela estão coordenando encontros para discutir a necessidade do planejamento regional para a infraestrutura. Já para Gonzalo Berrón (2015), a lógica da IIRSA, baseada em corredores de exportação, não foi alterada pelo Cosiplan, que manteve a essência produtivista da IIRSA, com poucas exceções.

Com uma visão oposta, Diego Cardona (2014) afirmou que ocorreram transformações substanciais com a incorporação da IIRSA à Unasul. Com a criação do Cosiplan, houve uma mudança de diretriz, com a priorização de projetos voltados para a integração física do interior da América do Sul. Ao contrário da IIRSA, que tinha uma concepção técnica, o Cosiplan passou a adotar uma perspectiva integral, incorporando novos temas e estimulando a coordenação entre diferentes setores e agências burocráticas. Nessa mesma direção, João Carlos Parkinson (2014) disse que o Cosiplan é um mecanismo mais sofisticado do que os corredores de exportação da IIRSA. O novo conselho modificou a ideia de eixo de exportação ao introduzir novos elementos para a análise dos projetos de infraestrutura, a exemplo de preocupações com impactos nas áreas ambiental, social e territorial. Essas questões passaram a ser consideradas pelo Cosiplan, diferentemente do que ocorria com a IIRSA.

A concepção de regionalismo ou integração regional encontra-se diretamente relacionada com a visão sobre a infraestrutura e o desenvolvimento dos espaços. Por um lado, uma visão liberal e geoeconômica prioriza o papel dos mercados na facilitação dos fluxos e na formação de corredores de exportação/importação. Por outro, uma visão desenvolvimentista e geopolítica enfatiza a importância do Estado no planejamento de corredores de desenvolvimento "para dentro", com o objetivo de formar um amplo mercado regional. No momento, falta consenso entre os países sul-americanos quanto ao tipo de integração regional e de inserção política e econômica no sistema internacional. Nesse cenário de crise internacional e regional, a 
Unasul e seus países membros têm como desafio construir uma visão integrada e de longo prazo em relação à integração física da América do Sul, tarefa que certamente não é fácil.

Em resumo, ao longo desta seção, analisou-se a fragmentação territorial que tem caracterizado historicamente a América do Sul. Nos anos 1990, o pensamento neoliberal influenciou temas como a integração regional. As propostas de regionalismo aberto da CEPAL e do novo regionalismo do BID foram decisivas na estruturação da IIRSA. Influenciada por instituições financeiras multilaterais, esta deveria ser funcional ao processo de liberalização econômica regional e viabilizar investimentos privados para construir corredores de exportação/importação. Com a ascensão dos governos progressistas, a iniciativa passou a ser criticada e acabou sendo incorporada à Unasul, por meio do Cosiplan, o qual aumentou a participação dos governos e agregou uma visão política ao processo de integração física da região. Apesar de introduzir novas questôes, o Conselho possui muitas limitações. Além da crônica restrição de financiamento, observa-se a ausência de um planejamento público regional e maior participação dos Estados e da sociedade na formulação dos projetos de integração.

\subsection{Síntese do capítulo}

Este capítulo procurou analisar as características do capitalismo de Estado no Brasil e a expansão das empresas brasileiras na América do Sul. Na primeira seção, foram analisadas as diferentes trajetórias do desenvolvimento capitalista no Leste Asiático e na América Latina após a Segunda Guerra Mundial. Para compensar seu atraso histórico, a industrialização tardia da periferia adotou um processo de crescimento de base institucional, apoiado em forte intervenção estatal no domínio econômico. No entanto, os resultados alcançados dependeram de elementos, como a formação dos Estados, as relações entre os setores público e privado e o tipo de inserção internacional. 
Os países asiáticos realizaram profundas reformas estruturais, limitaram a presença do investimento externo, fortaleceram as capacidades burocráticas e criaram grandes empresas nacionais nos setores de maior tecnologia. De maneira diversa, os países latino-americanos não realizaram reformas estruturais, não construíram sólidas capacidades estatais, nem lograram desenvolver setores dinâmicos da economia, que foram dominados por grupos transnacionais. $\mathrm{O}$ conjunto dessas características ajuda a explicar as razões do sucesso asiático e do relativo fracasso latino-americano em construir economias mais desenvolvidas e sociedades mais igualitárias.

A segunda seção analisou o processo de desenvolvimento e expansão do capitalismo brasileiro. Entre 1930 e 1980, o Brasil alcançou elevadas taxas de crescimento econômico e transformou sua estrutura produtiva, tornando-se o país mais industrializado da América Latina. Desde sua criação, o BNDES teve um papel decisivo na consolidação do capitalismo e do setor privado nacional, pois participou de todas as fases do desenvolvimento do país, fortaleceu grandes grupos econômicos e promoveu sua internacionalização. A atuação de poderosas empresas, sobretudo das empreiteiras, tem causado conflitos com os países vizinhos, com reflexos na política externa brasileira. A expansão da fronteira econômica vem provocando uma percepção negativa de alguns países, que veem o Brasil como um país subimperialista. No entanto, as análises nesse sentido carecem de mais fundamento teórico e costumam superdimensionar a presença dos capitais brasileiros na região. Ademais, entram em contradição com propostas de regionalismo autônomo representadas pela Unasul. Diante dos impactos negativos, portanto, cabe ao Brasil superar as contradições envolvendo a expansão de sua fronteira econômica e a dimensão geopolítica do novo regionalismo sul-americano apoiado por sua política externa.

$\mathrm{Na}$ terceira seção, analisou-se o processo de fragmentação histórica da América do Sul, a proposta de integração da infraestrutura apresentada pelos governos neoliberais e a tentativa recente de 
reconfigurar o processo integrativo. Em 2000, o governo Fernando Henrique propôs a IIRSA, um plano de integração da infraestrutura sul-americana totalmente compatível com a liberalização econômica internacional, que tinha uma visão geoeconômica da infraestrutura e priorizava a facilitação dos fluxos e a construção de corredores de exportação/importação, ligando a região aos mercados globais. Com a ascensão dos governos progressistas, as críticas a esse modelo levaram à incorporação da IIRSA pela Unasul, com a criação do Cosiplan. O novo conselho agregou uma visão política ao processo de integração física, estimulou uma maior participação dos Estados e levantou a necessidade de construir corredores de desenvolvimento voltados para dentro do subcontinente. Além disso, chamou a atenção para o impacto da infraestrutura em questões ambientais, sociais e territoriais. Apesar dos esforços, a brecha de infraestrutura continua enorme, faltam recursos para financiar os projetos e ainda há necessidade de uma participação mais forte do Estado e da sociedade no planejamento da infraestrutura física da América do Sul. 